
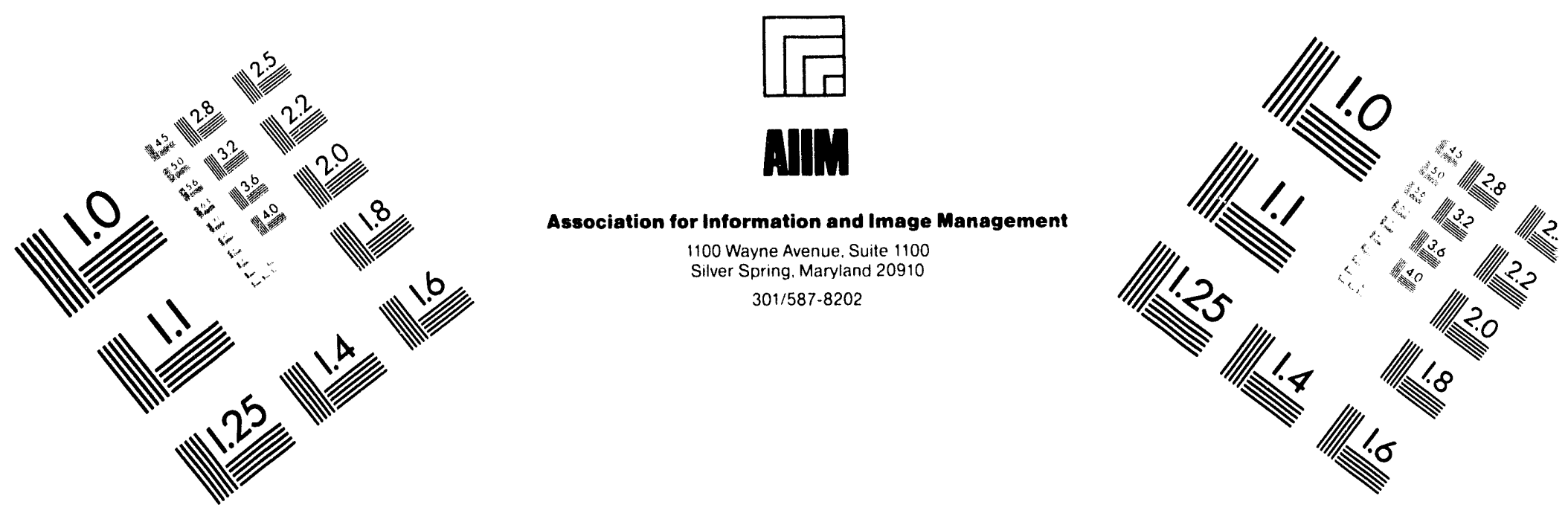

\title{
Centimeter
}

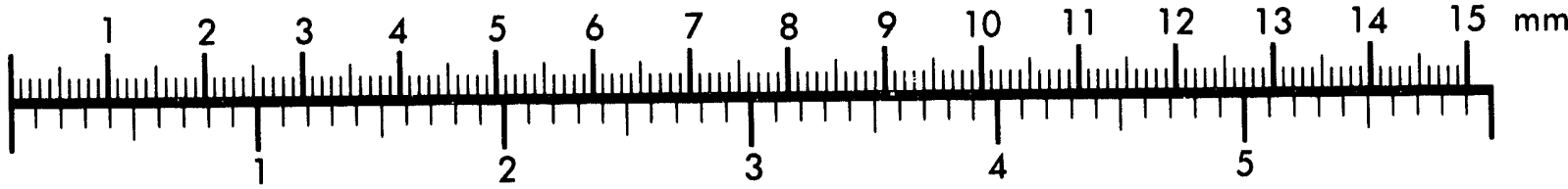
Inches
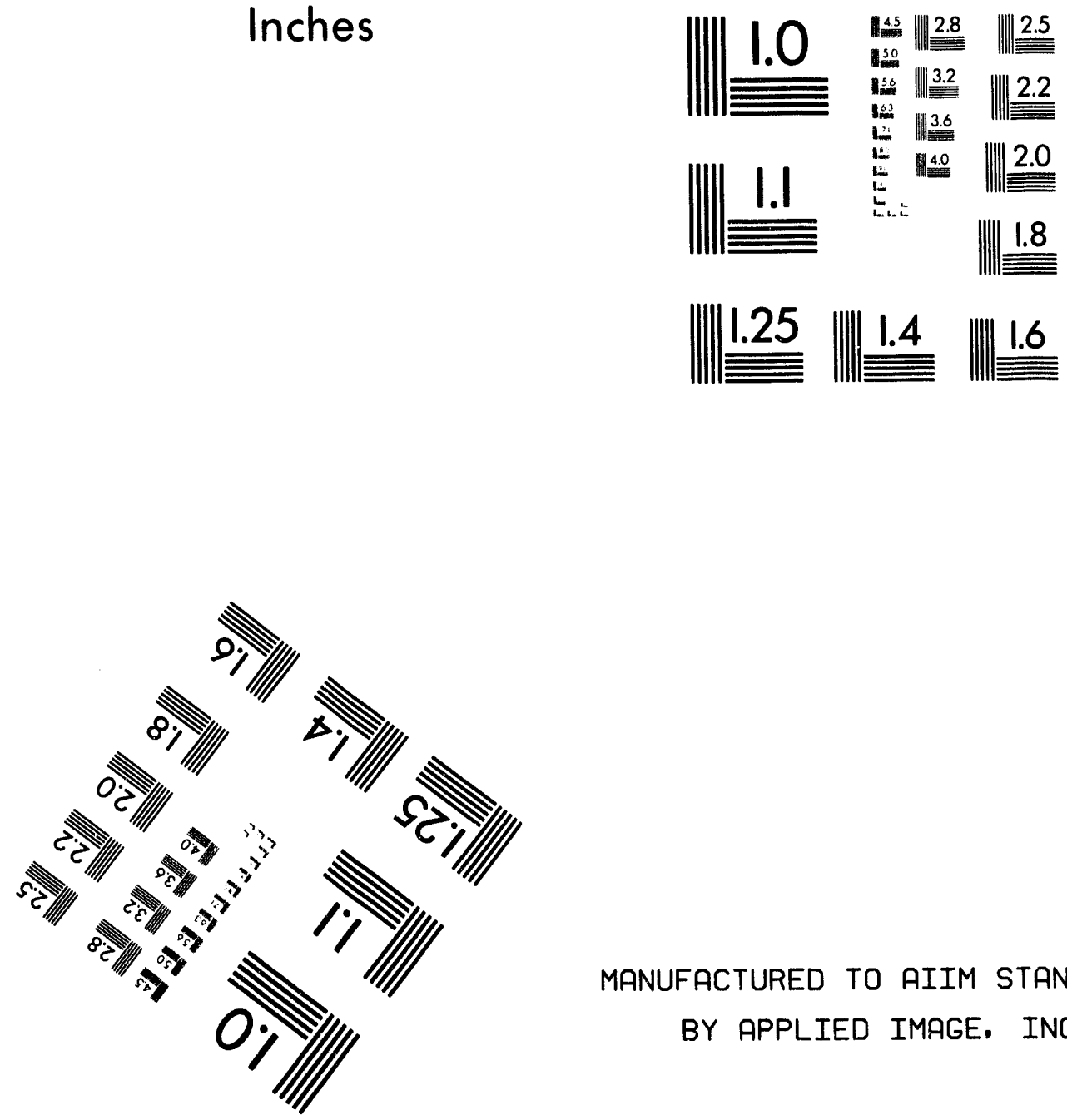

MANUFACTURED TO AIIM STANDARDS

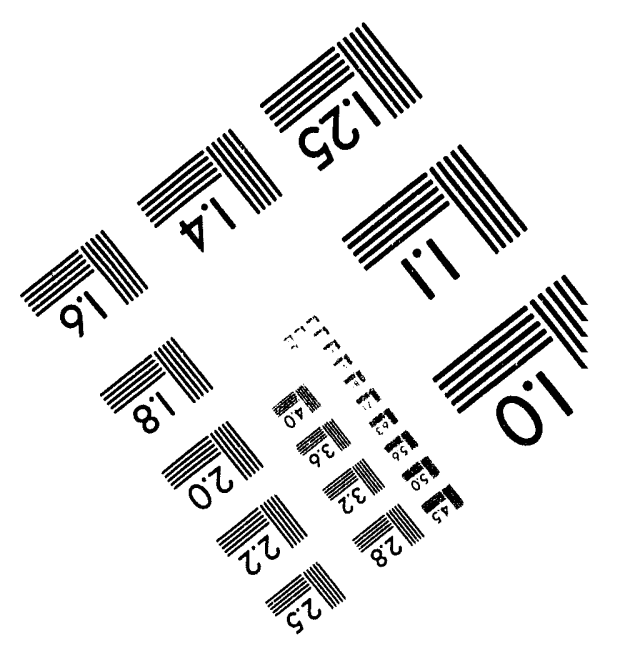



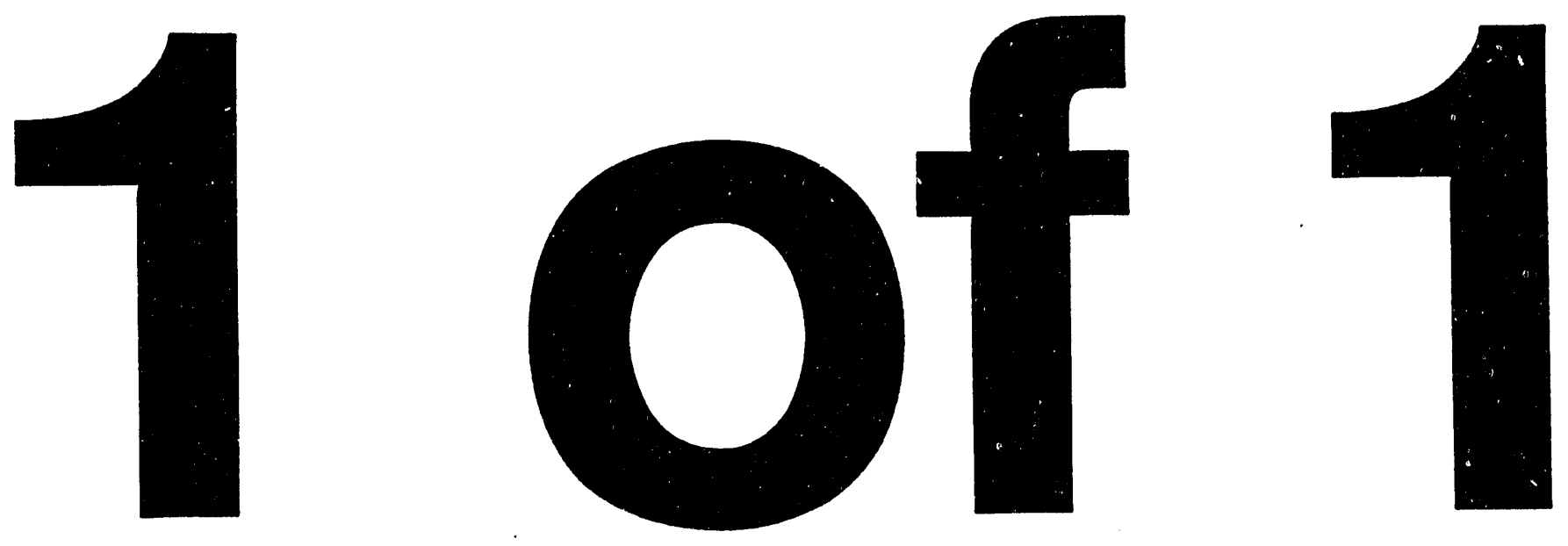


\section{Diesel Fuel Component Contributions to Engine Emissions and Performance: Clean Fuel Study}

J. Erwin, T.W. Ryan III, D.S. Moulten DOE Alternative Fuel Center Southwest Research Institute San Antonio, Texas

NREL technical monitor:

C. Colucci

\section{NPEI}

National Renewable Energy Laboratory 1617 Cole Boulevard Golden, Colorado 80401-3393 A national laboratory of the U.S. Department of Energy Managed by Midwest Research Institute for the U.S. Department of Energy Under Contract No. DE-AC36-83CH10093

Prepared under Subcontract Number YZ-2-11215-1 


\section{NOTICE}

This report was prepared as an account of work sponsored by an agency of the United States government. Neither the United States government nor any agency thereof, nor any of their employees, makes any warranty, express or implied, or assumes any legal liability or responsibility for the accuracy, completeness, or usefulness of any information, apparatus, product, or process disclosed, or represents that its use would not infringe privately owned rights. Reference herein to any specific commercial product, process, or service by trade name, trademark, manufacturer, or otherwise does not necessarily constitute or imply its endorsement, recommendation, or favoring by the United States government or any agency thereof. The views and opinions of authors expressed herein do not necessarily state or reflect those of the United States government or any agency thereof.

Available to DOE and DOE contractors from:

Office of Scientific and Technical Information (OSTI)

P.O. Box 62

Oak Ridge, TN 37831

Prices available by calling (615) $576-8401$

Available to the public from:

National Technical Information Service (NTIS)

U.S. Department of Commerce

5285 Port Royal Road

Springfield, VA 22161

(703) $487-4650$ 


\section{Executive Summary}

The work that is the principal subject of this report is covered by Task 3 of Project YZ-2-11215-1, "Diesel Fuel Component Contributions to Engine Emissions Performance." The technique used in this study resembled other petroleum assays, resulting in the name Diesel Fuel Assay. The present report builds on the previous tasks and earlier reports to describe a Clean Fuel Study of low-emissions test fuels.

\section{Introduction}

The emissions characteristics of diesel engines are dominated by current engine design parameters as long as the fuels conform to the current industry-accepted specifications. The current and future emissions standard, are low enough that the fuel properties and compositions are starting to play a more significant role in meeting the emerging standards. The potential role of the fuel composition has been recognized by state and federal govemment agencies, and for the first time, fuel specifications have become part of the emissions control legislation.

\section{Background}

The overall goal of this project was to develop relationships between the composition and properties of various petroleum and altemative fuel stocks and the emissions and combustion characteristics of these fuels. This was done in a series of experiments in which several fuels were tested in both a constant volume combustion apparatus and a single-cylinder research engine. The results of the fuel processing and characterization studies, and the preliminary engine test fuels were reported in three, peer-reviewed technical papers. The immediate goals of the Clean Fuel Study are discussion of the results of statistical analysis of these data, and the utilization of the results of these analyses to develop several formulations of low emissions diesel fuels.

\section{Approach}

In this work, five different fuel feed and blend stocks were hydrotreated to two levels of sulfur and aromatic content. These materials were then each distilled to seven or eight fractions of congruent boiling points. After this, the raw materials and all of the fractions were characterized by a complement of tests from American Society for Testing and Materials and by hydrocarbon-type analyses. The sample matrix was subjected to a series of combustion bomb and engine tests to determine the ignition, combustion, and emissions characteristics of each of the 80 test materials.

\section{Results}

The resulting data base was used in statistical analyses to develop relationships between the emissions characteristics and the fuel properties and composition measurements. The results of these analyses indicated linear relationships for:

$$
\begin{array}{ll}
\text { - NOx } & \text { - Hydrocarbons } \\
\text { - Smoke } & \text { - Cetane number. }
\end{array}
$$

As an application of the emissions correlations, low-emissions test fuels were formulated. Linear programming techniques were used to formulate 10 different compositions to meet specific emissions targets designed to approach future emissions standards. The trends for the predicted emissions levels and the actual emissions agreed with each other for the speed-load range of the engine test. The measured emissions characteristics were, in fact, much better than the target values or even the corresponding baseline data for most of the low-emissions fuels. 


\section{Table of Contents}

Section

Page

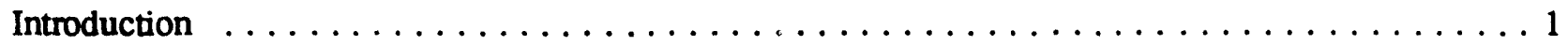

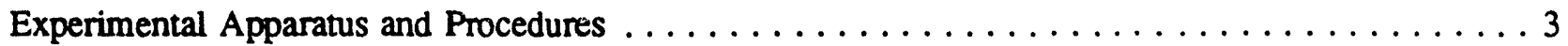

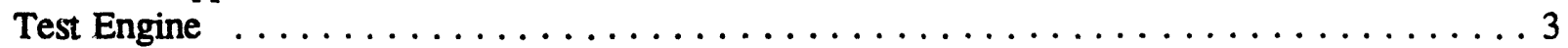

Test Procedures $\ldots \ldots \ldots \ldots \ldots \ldots \ldots \ldots \ldots \ldots \ldots \ldots \ldots \ldots \ldots \ldots \ldots \ldots \ldots$

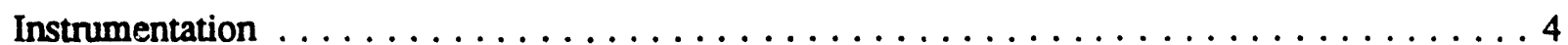

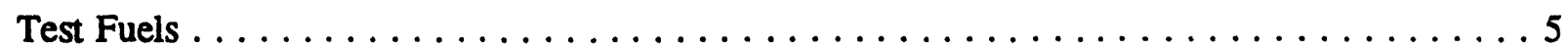

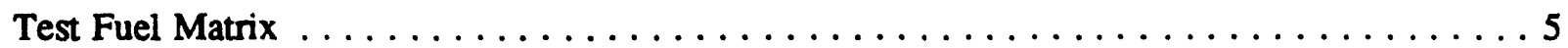

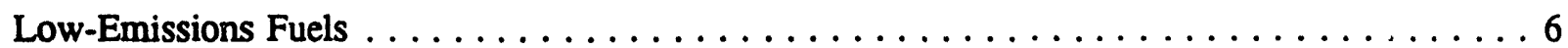

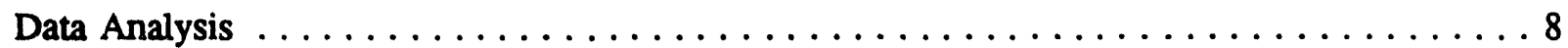

Experimental Results and Discussion $\ldots \ldots \ldots \ldots \ldots \ldots \ldots \ldots \ldots \ldots \ldots \ldots \ldots \ldots$

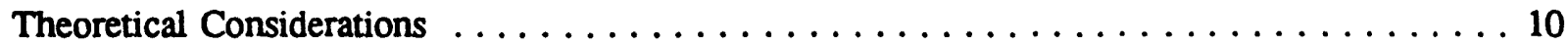

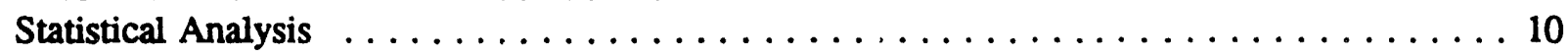

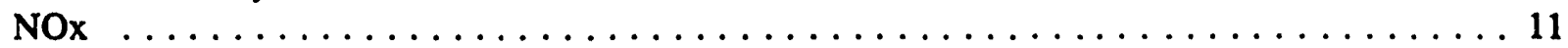

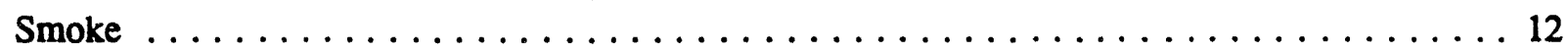

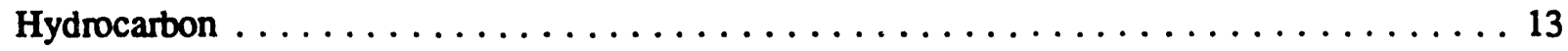

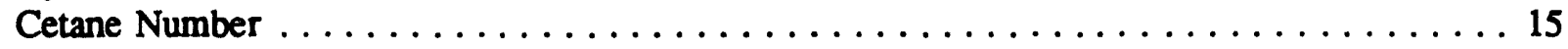

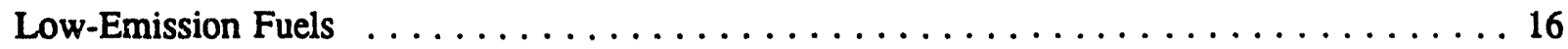

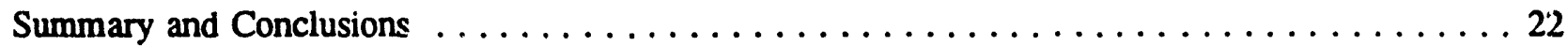

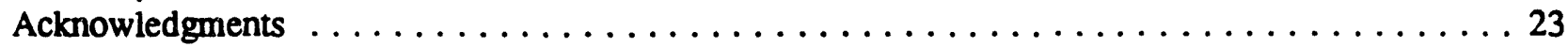

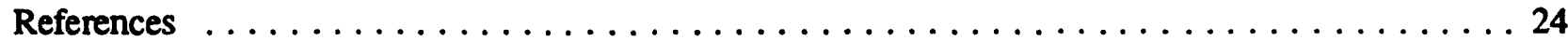

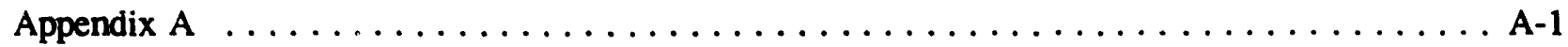

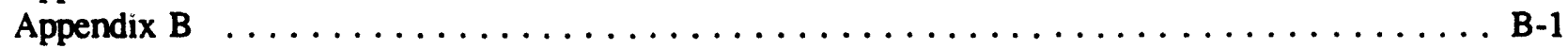

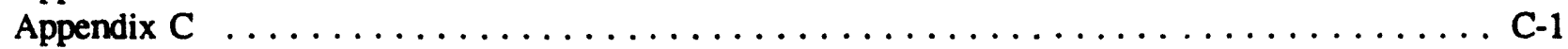

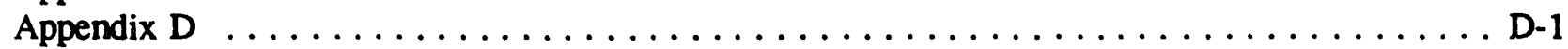




\section{List of Figures}

Figure

Page

1 Hydrocarbon emissions versus fuel fraction for the Fischer-Tropsch fuels at Mode $2 \ldots \ldots \ldots 14$

2 Bosch smoke number versus fuel fraction for the Fischer-Tropsch fuels at Mode $2 \ldots \ldots \ldots 14$

3 Aromatic content of the low-emissions fuels $\ldots \ldots \ldots \ldots \ldots \ldots \ldots \ldots \ldots \ldots$

4 Variable combustion ratio cetane numbers of the low-emissions fuels $\ldots \ldots \ldots \ldots \ldots \ldots$

5 NOx emissions for the low-emissions fuels at Mode $2 \ldots \ldots \ldots \ldots \ldots \ldots \ldots$

6 Hydrocarbon emissions for the low-emissions fuels at Mode $2 \ldots \ldots \ldots \ldots \ldots \ldots$

7 CO emissions for the low-emissions fuels at Mode $2 \ldots \ldots \ldots \ldots \ldots \ldots \ldots$

8 Bosch smoke numbers for the low-emissions fuels at Mode $2 \ldots \ldots \ldots \ldots \ldots \ldots$

9 Emissions parameter for the low-emissions fuels at Mode $2 \ldots \ldots \ldots \ldots \ldots \ldots \ldots \ldots$

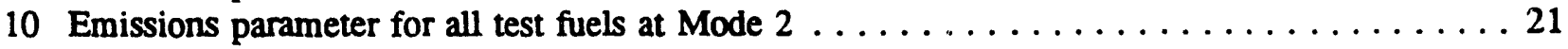




\section{List of Tables}

Table

Page

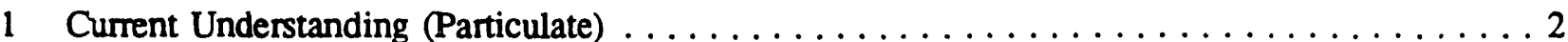

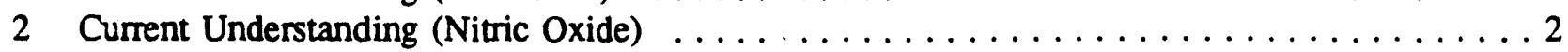

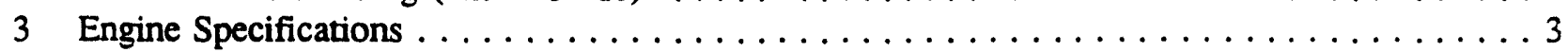

4 Test Conditions for Ignition Quality Rating $\ldots \ldots \ldots \ldots \ldots \ldots \ldots \ldots \ldots \ldots \ldots$

5 Test Conditions for Performance and Emissions $\ldots \ldots \ldots \ldots \ldots \ldots \ldots \ldots \ldots$

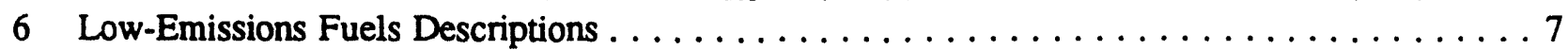

7 Computed and Measured Properties of the Low-Emissions Fuels $\ldots \ldots \ldots \ldots \ldots \ldots$ 


\section{Introduction}

The emissions characteristics of both spark ignition and diesel engines are dominated by engine design parameters as long as the fuels conform to the current industry-accepted specifications. The current and future emissions standards, however, are so low that the fuel properties and composition are starting to play a more significant role in the meeting the emerging standards. The potential role of the fuel composition has been recognized by state and federal govermment agencies. and for the first-time, fuel specifications have become part of the emissions control legislation.

The Altemative Fuels Utilization Program (AFUP) foresaw the need for a base case against which to compare the performance of altemative fuels and initiated the Diesel Fuel Assay. The need for comparative emissions performance applies equally to all alternative fuels, and the inclusion of one such alternative stock, indirect liquefaction coal diesel, gives detail for the application of the results of the assay.

Diesel fuel reformulation is under way in the United States, with limits imposed by the Environmental Protection Agency on the sulfur content $(0.05$ mass \%) and a lower limit on the cetane index of 40 . The State of Califomia is imposing an additional limitation on the effective maximum concentration of aromatics, at 10 volume \%. The results of the Coordinating Research Council VE (Vehicle Emissions) Program reported by Ullman 1989, indicate that the limits on sulfur and aromatics are consistent with the research, but the cetane number (CN) was also shown to be important. More recent work by McCarthy (1992, Miyamoto et al. (1992) and Nikanjam (1993) support these findings on the CN for nitric oxide and the particulate emissions. Betts et al. (1992) and Cowley et al. (1993), however, concluded that the aromatic content is not important in controlling the particulate emissions.

The current understanding of the effects of diesel-fuel properties on engine emissions is summarized in Table 1 for the particulate emissions and in Table 2 for nitric oxide (NOx) emissions. The arrows indicates the direction of change of the emissions as the property is increased. Missing arrows indicate that the author did not examine the particular property. The trends include those reported by the authors mentioned above, as well as others. The consensus is that the particulate emissions are controlled by the aromatic content, the $\mathrm{CN}$, and the sulfur content, and to a lesser extent by the high end of the distillation range and the density. The nitric oxides are controlled by the aromatics and the $\mathrm{CN}$, with one author reporting an effect of sulfur and distillation and another reporting an effect of the density.

The goal of the work reported here was to develop the start of a data base describing, in greater detail, the relationship between properties and composition of the fuel and diesel engine ignition, combustion, and emissions. The approach included the use of a large fuel matrix that utilized feed stocks and processing steps that are representative of current refining practice. detailed analysis of those test fuels, and both engine and combustion bomb testing of narrow-boiling distillation fractions of the fuels. The test fuels were a straight-run diesel, light cycle oil, light coker gas oil, and two Fischer-Tropsch coal liquids. The petroleum stocks that were chosen emphasized aromatics-bearing streams, light cycle oil and light coker gas oil, which represent the greatest challenge to performance and emissions. The results of the fuel preparation and characterization work were presented previously Erwin (1992). The results of the combustion bomb experiments were described by Ryan (1993), and preliminary analysis of the engine test results were also reported. A complete listing of the experimental resuits and summaries of the fuel property data are presented in that reference. Details of the statistical analysis of the engine test data are given in this report. In addition, the results of the statistical analysis were used to design several "lowemissions" fuels. The engine test results for these fuels are also presented and compared to emissions targets and with predictions from the statistical analysis. 
Table 1. Current Understanding (Particulate)

\begin{tabular}{lccccc}
\hline \multicolumn{1}{c}{ Author } & Aromatic & Cetane & Sulfur & Distillation & Density \\
\hline Burley (1979) & $\uparrow$ & $\uparrow$ & & $\uparrow$ & \\
Tosaka (1989) & $\uparrow$ & & & & \\
Uliman (1989) & $\uparrow$ & $\uparrow \downarrow$ & $\uparrow$ & $\uparrow$ & \\
McCarthy (1992) & $\uparrow$ & $\downarrow$ & & & $\uparrow$ \\
Asumi (1992) & $\uparrow$ & & $\uparrow$ & & \\
Betts (1992) & Not & $\downarrow$ & $\uparrow$ & $\uparrow$ & $\uparrow$ \\
Nikanjam (1993) & & $\downarrow$ & & & \\
Miyamoto (1992) & $\uparrow$ & $\downarrow$ & & & \\
Cowley (1993) & Not & $\downarrow$ & $\uparrow$ & & \\
Bertoli (1993) & $\uparrow$ & $\uparrow$ & $\uparrow$ & Not & $\uparrow$ \\
Ryan (1989) & $\uparrow$ & $\uparrow$ & & $\uparrow$ & \\
\hline
\end{tabular}

Table 2. Curremt Understanding (Nitric Oxide)

\begin{tabular}{lccccc}
\multicolumn{1}{c}{ Author } & Aromatic & Cetane & Sulfur & Distillation & Density \\
\hline Burley (1979) & & & & & \\
Tosaka (1989) & & & & & \\
Ullman (1989) & $\uparrow$ & $\downarrow$ & $\downarrow$ & $\downarrow$ & \\
McCarthy (1992) & $\uparrow$ & $\downarrow$ & & & \\
Asumi (1992) & $\uparrow$ & & & & \\
Betts (1992) & & & & \\
Nikanjam (1993) & $\uparrow$ & $\downarrow$ & & \\
Miyamoto (1992) & $\uparrow$ & $\downarrow$ & & \\
Cowley (1993) & & & & \\
Bertoli (1993) & & $\downarrow$ & & \\
Ryan (1989) & $\uparrow$ & $\uparrow$ & & \\
\hline
\end{tabular}




\section{Experimental Apparatus and Procedures}

Details of the engine and the test procedure were presented previously (Ryan 1993). The most important aspects of that description are repeated here for convenience. Two types of engine experiments were performed. Each fuel was rated for ignition quality following a modified cetane rating procedure that accounted for the differences in design and operation of the test engine compared to those of the standard Consolidated Fuels Research (CFR) engine of American Society for Testing and Materials (ASTM) D 613 method. The fuels were also tested for emissions and performance at five different speed-load test conditions, representative of different operating regimes of the engine. Details of the engine design and configuration are reviewed in this section. In addition, the test conditions, procedures, and fuel matrix are described in detail.

\section{Test Engine}

The test engine is a specially designed, single-cylinder research engine. The configuration consists of a two-valve, direct-injection design with the added feature of variable compression ratio, achieved by moving the head and cylinder liner assembly relative to the centerline of the crankshaft. A variation from 12:1 to 20:1 compression ratio was possible in the configuration used for these experiments. The engine is geometrically similar to current two-valve engines, with a similar bore-to-stroke ratio and a shrouded intake valve to produce a swirl ratio of 2.7. Details of the engine configuration are presented in Table 3.

Table 3. Engine Spectifications

\begin{tabular}{lc}
\hline Bore $\times$ Stroke $(\mathrm{mm})$ & $96.5 \times 95.3$ \\
Rod Length $(\mathrm{mm})$ & 166.5 \\
Compression Ratio & $12: 1$ to $20: 1$ \\
Displacement $(\mathrm{cc})$ & 767.2 \\
Deck Height $(\mathrm{mm})$ & 7.9 to 0.4 \\
Injection Pump $(\mathrm{mm} \times \mathrm{mm})$ & $11 \times 11$ \\
Injection Pressure $(\mathrm{MPa})$ & 100 \\
Combustion Chamber & Mexican Hat \\
Re-entrant & \\
Re-entrant Angle & $25^{\circ}$ \\
Bowl Opening $(\mathrm{mm})$ & 43.3 \\
Bowl Depth $(\mathrm{mm})$ & 19.3 \\
Swirl Ratio & 2.7 \\
\hline
\end{tabular}

The ignition quality rating procedure required the use of the variable compression ratio feature of the engine. Changing the compression ratio, however, also changes the deck height and the resulting squish velocities and optimum fuel spray angles. It was felt that the variation in squish velocity would have little impact on the ignition rating, but deviation from the optimum spray angle could result in fuel impingement 
outside the combustion chamber bowl. The ignition quality rating was therefore performed using a sixhole by 0.20 -mm diameter injection nozzle tip with a 110 degrees spray angle, to ensure that fuel injection was always completed inside the combustion chamber bowl. The performance and emissions testing, on the other hand, was performed at a fixed compression ratio, 17.9:1, so that it was possible to select an optimum injection nozzle tip configuration, which was determined to include four holes of $0.23-\mathrm{mm}$ diameter and a spray angle of 140 degrees (Ryan 1993).

\section{Test Procedures}

The procedure developed for ignition quality rating was based on operating the engine on a selected "standard condition" for both the test fuels and selected blends of the primary reference fuels for cetane rating (hexadecane with a $\mathrm{CN}$ of 100 , and heptamethylnonane with a $\mathrm{CN}$ of 15 ). The conditions that were selected for this work are listed in Table 4. The injection timing was fixed at 12 degrees Before Top Dead Center (BTDC). The engine was operated on each reference fuel blend, and the compression ratio varied until ignition occurred at Top Dead Center (TDC). A calibration curve was developed in which the $\mathrm{CN}$ was presented as a function of the compression ratio. The test fuels were then run at the "standard condition," and the compression ratio was varied to give ignition at TDC. This compression ratio was used with the calibration curve to determine the $\mathrm{CN}$.

Table 4. Test Conditions for Ignition Quality Rating

\begin{tabular}{lc}
\hline Speed & $900 \mathrm{rpm}$ \\
Air/Fuel Ratio (A/F) & $50: 1$ \\
Injection Timing & $12^{\circ} \mathrm{BTDC}$ \\
Intake Temperature & $38^{\circ} \mathrm{C}$ \\
Intake Pressure & $115 \mathrm{kPa}$ \\
Coolant Temperature & $66^{\circ} \mathrm{C}$ \\
\hline
\end{tabular}

Performance and emissions data were obtained at five test conditions. These data consisted of the normal power and efficiency measurements, engine heat-release analysis, and gaseous emissions and smoke. The test conditions included rated torque at fixed timing (Mode 1), rated torque using the best torque timing for each fuel (Mode 2), and three-part load conditions at the rated power speed (Modes 3-5). Details of the five sets of conditions are presented in Table 5.

\section{Instrumentation}

The amounts of test fuel available for testing were generally limited. Efforts were therefore made to minimize the quantity of fuel required for flushing and filling the fuel system. Fuel flow was measured volumetrically using a calibrated burette that was connected to both the fill and retum ports of the injection pump. The intake air was supplied using a large compressor. The air temperature, pressure, and humidity were all controlled. Air flow rate was measured and controlled using a metering control valve.

The engine temperatures and pressures were monitored using a personal-computer-based data acquisition system that logged the data every 30 seconds. A water-cooled piezoelectric pressure transducer was installed in the combustion chamber for measurement of the cylinder pressure. These data and the 
Table 5. Test Conditions for Performance and Emissions

\begin{tabular}{cccc}
\hline Designation & Speed & AF & Injection Timing \\
Mode 1 & 1200 & $28: 1$ & $3^{\circ}$ BTDC (rate torque) \\
Mode 2 & 1200 & $28: 1$ & Variable (best torque timing) \\
Mode 3 & 1500 & $28: 1$ & $3^{\circ}$ BTDC (part load) \\
Mode 4 & 1500 & $40: 1$ & $3^{\circ}$ BTDC (part load) \\
Mode 5 & 1500 & $50: 1$ & $3^{\circ}$ BTDC (part load) \\
\hline
\end{tabular}

corresponding injection pressure and nozzle needle lift data were logged every 0.5 degrees of crankshaft rotation, using a Preston Scientific A/D and a Hewlett Packard A900 computer system. A First Law analysis of the cylinder pressure was used to compute the heat-release rates. These analyses gave an indication of the quality of combustion

The exhaust emissions were sampled downstream of a mixing tank located in the exhaust of the engine. The gases were analyzed for $\mathrm{CO}_{2}$ and $\mathrm{CO}$ using nondispersive infrared. Hydrocarbons were measured using a flame ionization detector. Nitric oxides were measured using a chemiluminescence instrument. Smoke was determined using a Bosch smoke meter.

\section{Test Fuels}

Two sets of test fuels were prepared for use in this work. The first set consisted of a large matrix of fuels and fuel fractions that were selected and prepared specifically to examine the effects of fuel source, processing history, and properties on emissions. The test results were for developing relationships between the properties and the emissions. The properties of the base stocks and fractions are presented in Appendix C. These relationships were then the basis used to design a second set of "low- emissions" diesel fuels.

\section{Test Fuel Matrix}

Details of the fuel selection, preparation, and analysis were presented in a previous publication (Erwin 1992). Five different diesel fuel feed and blending stocks were selected to be representative of current and future feedstocks and refining technologies. The five feedstocks were hydrotreated to the same level of sulfur and also to the same level of total aromatics. Efforts to separate fuels such as these into the individual compounds have been partially successful in the laboratory. The number of compounds is extremely large, however, and it is therefore not feasible to study the combustion of each individual component and all of the possible interactions among the various components. A more practical approach, and the one used in this project, is to separate the fuels into a reasonable number of fractions by distillation for study in detail. Each fuel was thus separated by distillation into $40^{\circ} \mathrm{F}$ ranges of boiling points. Sufficient quantities of each of the fractions were prepared so that they could all be tested in the engine to determine the combustion and emissions characteristics of the individual fractions.

The test components included full-boiling straight-run diesel (SRD), light cycle oil from catalytic cracking (LCO), light coker gas oil (LCGO), and two types of coal-derived Fischer-Tropsch distillate (FT). The 
FT stocks consisted of two materials, a diesel from wax cracking and a straight-run fuel. Low-severity hydrotreating was used to lower sulfur content of the LCO and LCGO to $0.05 \mathrm{M} \%$ (SRD sulfur content was inherently low because of the crude oil from which it was made). High-severity hydrotreating of the LCO, the LCGO, and the SRD feedstocks produced low-aromatics products with 10 vol\% aromatics by ASTM D 1319. The FT liquids are synthetic products inherently free of sulfur and aromatics. The five feedstocks and five products were distilled into $6-8$ fractions each, producing 80 fractions that were available for analysis and testing.

Distillation of each of the five feedstocks and five products was done in a stainless-steel apparatus generally following the method of ASTM D 289.2. Narrow boiling range cuts were taken every $40^{\circ} \mathrm{F}$ from $400^{\circ}$ to $640^{\circ} \mathrm{F}$. The first and last cuts includea the initial boiling and final boiling points. The feedstocks and the fractions were all subjected to detailed ultraviolet, gas chromatograph/mass spectrometer (GCMS), and nuclear magnetic resonance (NMR) analysis, in addition to a standard battery of ASTM fuel characterizations.

\section{Low-Emissions Furls}

As will be described in another section, statistical analysis of the engine performance and emissions data indicated that the dominant fuel effects on the emissions were the aromatic content, aromatic type, $\mathrm{CN}$, and sulfur content. It also became clear, however, that much more detailed analysis was required to develop relationships between the various fuel properties and the emissions. In addition, the regression equations could not be used to compute the fiel composition required to meet certain emissions targets. A simplified approach was therefore taken in the design and formulation of a set of "low-emissions" diesel fuels. The approach consisted of including the measured emissions data with the laboratory results for each cut as properties for linear programming blend calculations.

Distillation of the test fuel components provided a large number of potential blend stocks for a set of lowemissions fuels. Collectively, the potential blend stocks contained a wide range of properties, and in general. several different blend formulations could be determined with properties meeting any particular set of specifications. The blend compositions of 10 low-emissions fuels designed according to 3 or 4 different concepts were determined using the linear programming (LP) technique for selecting an optimal solution from many acceptable solutions. This allowed rapid selection of a blend formulation that was best in the particular concept.

Several preliminary actions facilitated the selection process. The Mode 2 data were selected as the mos appropriate for the selection. Because the LP method optimizes on a singl: property, an "emissions parameter" was defines for each component by normalizing and adding the rrumalized emissions data in each concept. Normalization of the emissions data was accomplished 'y dividing the measured or predicted emissions data by the respective target value for each component. If the target emissions levels are achieved exactly for each emissions, the emissions parameter (EP) equals 4, corresponding to the four emissions that were considered. Values of EP below 4 indicate emissions levels better than the target, and values greater than 4 indicate that the target level was not achieved. The EP provides a convenient parameter for comparing different fuels, even if the target values are never achieved.

The targets, based on the Mode 2 rated torque condition, were:

- $4 \mathrm{sm} / \mathrm{hp}-\mathrm{h}$ for $\mathrm{CO}$,

- $2 \mathrm{grn} / \mathrm{hp}-\mathrm{h}$ for $\mathrm{HC}$.

- $5 \mathrm{gm} / \mathrm{hp}-\mathrm{h}$ for NOx and

- Number 2 for Bosch smoke. 
The LP problem was set up on the computer to include as many components as practical, and preliminary runs were made with the individual distillation cuts. Both the untreated light cycle oil and the high-boiling Fischer Tropsch products were excluded because it was not possible to test these materials under all conditions. The results showed that adjacent cuts were in general not selected in similar quantities, so more realistic, broad-range cut properties were calculated by linear combination of the individual cuts weighted by their yield. This provided about 215 different blendstocks, including the full boiling range products, available to the LP problem.

Two further actions helped reduce the scope to manageable proportions. The component properties were entered in a spreadsheet library and set up so they could be brought into the problem readily, allowing a large number of components to be tried rapidly by manual action. The other action reduced the number of formulas requiring trials. In addition to the blend formulation, the LP solution indicates the relative utility of unused components to the blend. Preliminary LP runs quickly established that similar cuts had similar utilities to the blends. For example, if a blend made of cuts three through five was not used in a blend and had low urility, a blend made of cuts three through six of the same product would also have low utility and would not be used. These actions allowed calculation of optimal blends from a set of fueis including the parent products and all the practical distillation cuts.

In general, the goals were to produce full boiling range fuels that would either provide the lowest possible emissions or would provide indications of the independent effects of aromatic content and CN. Several blend formulations were calculated. They differed in the constraints placed on the problem or the property that was optimized. Table 6 gives a description of each calculated blend. Fuel 1 was designed for the lowest possible emissions, using all of the available components. Fuel 2 had the added constraint of using the most of one of the least valued products, the low-aromatics light cycle oil (LALCO). Concentrations of light-cycle oil (LCO) and light-coker gas oil (LCGO), typical of actual refinery operation, were used to design the lowest possible emissions in Fuel 9. Fuel 10 had the same constraints as Fuel 1 except that the high-quality Fischer Tropsch materials were not included in the blend. Fuels 3 and 4 were designed to examine the effects of aromatic content, at a constant cetane number of 55. Fuels 5 and 6 were designed to examine the effect of $\mathrm{CN}$ at constant aromatic content of $15 \%$. Fuels 7 and 8 were designed to be the midpoints between Fuels 3 and 4, and Fuels 5 and 6, respectively.

Table 6. Low-Emissions Fuels Descriptions

\begin{tabular}{cl}
\hline Blend No. & \multicolumn{1}{c}{ Blend Concept Description } \\
\hline 1 & Minimum emissions \\
2 & Minimum emissions with maximum use of light cycle oil product (low-aromatics LCO) \\
3 & Minimum aromatics concentration with CN 55 to 56 \\
4 & Maximum aromatics concentration with CN 55 to 56 \\
5 & Maximum CN with aromatics $15 \%$ to $16 \%$ \\
6 & Minimum CN with aromatics $15 \%$ to $16 \%$ \\
7 & $50: 50$ mixture of blends 3 and $4^{*}$ \\
8 & $50: 50$ mixture of blends 5 and $6^{*}$ \\
9 & Minimum emissions with LCO and LCGO products in typical abundance \\
10 & Minimum emissions, FT products excluded \\
Not calculated directly by linear programming
\end{tabular}


In this way, linear programming was used to compute the blend compositions based on the property and emissions data for each component. The properties of each of the blends were also computed based on the assumptions of linear blending. The results of these calculations for the aromatic content and the CN are summarized in Table 7. The measured CNs, also listed in Table 7, are, in some cases, substantially different than the target values used in the linear programming, indicating the nonlinear nature of the cetane scale. The computed values of the other properties of the 10 low-emissions fuels are tabulated in Appendix A. Composition of Task 3 fuels and composition appear in Appendix D.

Table 7. Computed and Measured Properties of the Low-Emissions Fuels

\begin{tabular}{cccc}
\hline $\begin{array}{c}\text { Fuel } \\
\text { Number }\end{array}$ & $\begin{array}{c}\text { Aromatics } \\
\text { (wt \%) }\end{array}$ & $\begin{array}{c}\text { Computed } \\
\text { CN }\end{array}$ & $\begin{array}{c}\text { Measured } \\
\text { CN }\end{array}$ \\
\hline 1 & 10 & 70 & 62 \\
2 & 7.8 & 66 & 40 \\
3 & 0.7 & 57 & 43 \\
4 & 29 & 63 & 41 \\
5 & 15 & 75 & 60 \\
6 & 7.7 & 63 & 29 \\
7 & 15 & 60 & 41 \\
8 & 11.3 & 69 & 44 \\
9 & 8.7 & 73 & 56 \\
10 & 13.9 & 55 & 50 \\
\hline
\end{tabular}

\section{Data Analysis}

The data set for this work consisted of the fuel properties and composition information, in addition to the engine performance. emissions, and combustion data. The data set was subdivided into the ignition quality measurements and five sets of performance and emissions data, one set for each of the five test conditions.

It was therefore possible to examine the effects of the fuel properties independent of the engine test conditions. Each of the performance and emissions data sets inciuded 81 fuel and engine combustion, performance, and emissions variables. The variable names and descriptions are listed in Appendix B.

Preliminary analysis of the data included scatter plots of each of the dependent variables (CO, HC, NOx, smoke number) versus many of the independent variables. This approach revealed strong relationships between both the ignition quality and emissions variables and the fuel fraction. These relationships indicated that the dependent variable (emissions parameter) is related to the boiling point of the fuels. In addition, the aromatic content of some of the fuels was also strongly related to the boiling point (Ryan 1993; Ryan, 1992).

Initial statistical analysis included stepwise regression of each type of the emissions measurements as functions of all of the independent variables, as well as functions of various subsets of the independent variables that included the physical properties, the chemical properties and composition, and the combustion characteristics. These analyses provided an indication of which subset of fuel variables 
accounted for most of the variation of a given dependent variable. The stepwise analysis was used to identify variables that were colinear and also those that provided little information in the regression analysis. These stepwise analyses were followed by best-fit regression that included all possible combinations of a reduced set of independent variables. The results of the all-possible regressions were used to select the best set of fuel properties to use in constructing the prediction equations for all dependent variables at all test conditions. Residuals from each of the chosen regression fits were examined to determine if nonlinear fuel or emission effects were present. The results indicated that linear relationships were adequate for the range of the data examined in this work.

The best-fit regression equations provide predictions of the emissions in terms of the selected set of fuel properties. Calculation of the fuel properties to meet emissions targets is not possible with the regression equations; that is, they cannot be inverted to compute the fuel properties based on emissions targets. The observation of linear relationships, however, justified the use of linear programming techniques to formulate fuels to meet specific emissions targets. 


\section{Experimental Results and Discussion}

The statistical correlations and interpretations of the experimental results (emissions measurements) are presented for the test fuel matrix. Relationships between the ignition quality and the emissions characteristics are presented with emphasis on variations attributable to fuel properties. The role of various subsets of the properties, including physical, chemical, and combustion properties, are discussed in terms of the relative importance of these specified subsets at each operating condition (or Mode). The data are then discussed in global terms based on a defined Emissions Parameter (EP). The performance of the low-emissions fuels are also presented and discussed in the same terms.

\section{Theoretical Considerations}

The set of five test conditions represents fairly radical differences in the thermodynamic and overall stoichiometric conditions used to study each fuel. As indicated, Mode 2 represents the maximum torque condition of the engine. Mode 1 conditions are identical to Mode 2, except that the injection timing is retarded to 3 degrees BTDC for NOx control. Mode 1 therefore represents a lower temperature and pressure condition than does Mode 2. Differences in the NOx emissions at Mode 2 are therefore more sensitive to fuel effects than are those at Mode 1 because of optimization of the timing for best torque or efficiency. Smoke numbers at Mode 2 are also probably more dependent on the fuel properties than are those at Mode 1 because of retarded timing at Mode 1 and the corresponding dependence on the physical processes such as delayed fuel evaporation at the lower temperatures occurring in Mode 1.

Mode 3 is the rated power condition with the injection timing retarded to 3 degrees BTDC for NOx control. Like those at Mode 1, the emissions at Mode 3 are probably dominated by physical processes and properties, rather than fuel chemical properties and composition. Modes 4 and 5 are part-load conditions at the rated power speed, at which the physical processes of fuel mixing are dominated by reduced injection pressure, and which in tum dominates the NOx and smoke emissions.

It is anticipated that the $\mathrm{CO}$ emissions are controlled primarily by the overall air-fuel ratio and the combustion efficiency. The HC emissions are dominated by the physical processes of air-fuel mixing, quenching, and the physicochemical properties that control these processes, such as the boiling range and the viscosity. It should be realized, however, that there are also relationships between the fuel composition and these physical properties. It was felt. however, that the use of fuel fractions of narrow boiling range would make it possible to separate the effects of these physical and chemical properties. Another consideration is that $\mathrm{CN}$ is a dependent variable as a performance parameter, and it is an independent variable in the models in which emissions are the dependent variables being correlated.

\section{Statistical Analysis}

The results of the statistical analysis verified that Mode 2 represented the best test condition for examining the fuel composition and property effects on the NOx, smoke, and hydrocarbon emissions. The stepwise analysis was first performed using three subsets of the independent variables. The subsets were defined to include the combustion parameters, the physical properties, and the chemical properties. Although different properties could have been included in each subset. the goal was to determine where, or if, the physical or chemical properties, or the combustion parameters dominated the emissions characteristics. For instance, one overall result was that power and $\mathrm{CO}$ emissions did not display significant fuel dependence at any combination of test conditions.

The combustion properties include the air-fuel ratio, peak combustion pressure, peak heat-release rate, the angles of occurrence of these peak values, beginning of injection, indicated and brake power, energy input. 
cumulative heat release, and the combustion efficiency. NOx emissions were highly correlated with the combustion characteristics at the rated power and rated torque conditions, with $R^{2}$ in the range of 0.97 . The $\mathbf{R}^{2}$ dropped dramatically at the part load conditions. The other emissions were not highly correlated with the combustion parameters, based on $R^{2}$ values below 0.5 .

The fuel physical properties considered include average boiling point, heating value, initial boiling point. T50, T95, specific gravity, viscosity, CN, volume percent aromatic, olefins, and saturates, and at wt \% carbon, hydrogen, and sulfur. The NOx emissions displayed dependence on the T50, the specific gravity, the heating value, and the vol\% aromatics at all but the lightest load condition. The smoke number was correlated ( $R^{2}$ in the range of 0.5 to 0.75 ) mainly with the boiling point distribution and the viscosity across the load range, indicating a dominance of the physical processes on the soot formation and oxidation.

The stepwise regression analysis included a very broad range of chemical composition variables. The initial analysis included both the NMR characterizations and the GC/MS hydrocarbon-type breakdowns. As expected, the NMR and the GC/MS data were highly colinear. The NIMR data provide a great deal of structural information regarding the location and environment of the hydrogen within the fuel molecules, and in that sense provide more information regarding the structure of the fuel. The statistical analysis indicated that both the NMR and the GC/MS data provided nearly equivalent representations of the results. It was felt that the NMR parameters are somewhat more difficult to obtain, and therefore the subsequent statistical analysis included only the component hydrocarbon composition data obtained by GC/MS. NOx emissions displayed a strong dependence, across the speed and load range of the engine, on the hydrocarbon type data, with $R^{2}$ in the range of 0.6 to 0.8 . The ignition quality, in terms of the engine-based $\mathrm{CN}$, was also highly correlated with the chemical composition.

As indicated previously, the stepwise regression analysis was followed by linear fits using all possible combinations of those fuel variables found to be important in one or more of the fits for each subset. The results of these analyses were used as the basis for selecting the best linear models for each independent variable at each test condition. While scatter plots of the residuals (degree of statistical fit of each dependent variable) were indicative of linear behavior, efforts were made to improve the linear models using natural log transformations, curvilinear, and interactive terms. The $\mathbf{R}^{2}$, or fit, of the model fits were not improved by the inclusion of these nonlinear terms.

The final models for each of the emissions were developed at each speed-load condition. The results of these analyses for the Mode 2 test condition appear to present the best indication of the effects of the fuel properties and composition on the $\mathrm{CN}$ and the emissions. The Mode 2 models are discussed in detail in the following paragraphs.

NOx

The NOx emissions were highly correlated with the combustion parameters, reflecting the kinetic nature of the NOx formation mechanism. The Zeldovich (1946) kinetic model for NO relates the formation process to the concentrations of the nitrogen and oxygen species in the flame zone and the time and temperature of reaction. The local adiabatic flame temperature is appropriate for use in the Zeldovich mechanism. The adiabatic flame temperature and the overall combustion rate are directly related to the chemical composition of the fuel. These dependencies are reflected in the regression equation that was developed for NOx, where 
NOx $=A_{1}+A_{2} \times$ (Alkylnaphthalenes)

$+A_{3} \times$ (Indenes $)+A_{4} \times($ Percent Carton)

where the concentrations are in wi \%, and the coefficients are:
$A_{1}=-96.34$
$\mathrm{R}^{2}=0.82$
$A_{2}=0.22$
$A_{3}=-0.24$
$A_{4}=1.17$.

The regression analysis included several variables describing the aromatic structure:

- Alkyl Benzenes

- Indanes/Tetralin

- Indenes

- Naphthalene

- Alkylnaphthalene

- Acenaphthylenes

- Acenaphthenes

- Tricyclics.

The results indicate that two-ring structures lead to higher NOx levels, while the level of unsaturation indicated by the indenes tends to lead to lower levels of NOx. The importance of the total aromatic nature of the fuel is probably reflected in the carbon content.

As indicated in the stepwise fits, the fuel's physical properties provided a good indication of the NOx trends when they alone were used in the regression analysis. The final regression equation did not include fuel physical properties, however, because the stepwise analysis indicated that the physical properties added little to the prediction of the NOx emissions when the chemical composition parameters are included in the analysis. This finding is related to the fact that the physical properties and the chemical composition are colinear in many cases.

\section{Smoke}

The smoke number reflects the soot fraction of the particulate emission. Soot emissions depend on the difference between the soot formation and the soot oxidation rates in the engine. A great deal of soot is formed during combustion in diesel engine cylinders, but most of this soot is oxidized prior to exhaust. The soot formation mechanism is dependent on fuel composition, the thermodynamic state in the combustion chamber, and the mode of combustion (premixed versus diffusion). The soot oxidation mechanism is dependent mostly on the thermodynamic state and the physical processes associated with mixing. Regression of the Bosch smoke data indicated that only a part of the variation could be accounted for in the fuel properties. This probably reflects the fact that the soot oxidation mechanism depends more on the physical processes than on the chemical composition of the fuel. The final smoke equation is 
Bosch Smoke $=A_{1}+A_{2} \times($ Acenaphthylenes $)$

$+A_{3} \times$ (Alkylbenzenes) $+A_{4} \times$ (Tricyclic Aromatic)

$+A_{5} \times($ Total Aromatics $)+A_{6} \times($ Vol\% Aromatics $)$

where the concentrations are in wt \% except as indicated, and where:

$$
\begin{aligned}
& A_{1}=2.24 \\
& A_{2}=-0.065 \\
& A_{3}=-0.029 \\
& A_{4}=0.08 \\
& A_{5}=0.027 \\
& A_{6}=-0.013
\end{aligned}
$$

The majority of the combustion event in the test engine occurred in diffusion buming of the fuel jets. Palmer and Curtis (1965) indicate the that tendency for soot formation in diffusion flames decreases in the order:

$$
\begin{gathered}
\text { naphthalenes }>\text { benzenes }>\text { diolefins }> \\
\text { monolefins }>\text { paraffins }
\end{gathered}
$$

where the tendency to form soot decreases in each group with increasing molecular weight (except the paraffins and increasing compactness.

The results of the regression analysis indicate a direct relationship with the total aromatic content and the concentration of three-ring aromatics. This effect is expected based on the conclusions of Palmer and Curtis (1965). The inverse relationship with the acenaphthylenes and the alkyl benzenes may be related to the decreased stability of the tertiary carbon atoms in these structures, the increased molecular weight, or the compactness of these groups of compounds. Inclusion of the vol\% aromatics provides a marginal improvement in the $\mathbf{R}^{2}$ and may reflect an interaction with the density.

It should be noted that the Bosch smoke number is not an accurate measurement of the total mass of soot emissions. The regression equations generated using these data reflect this limitation, and the resulting discussion should be considered in light of this limitation. Future experiments should consist of total mass measurements, with an actual breakdown between soot and the soluble fraction.

\section{Hydrocarbon (HC)}

It was surprising that the HC emissions decreased with increasing boiling point at all speed-load conditions. This relationship is demonstrated for the Fischer-Tropsch fuels in Figure 1, in which the HC emissions are plotted versus the fuel fraction or average boiling point. Figure 2 is a similar plot of the Mode 2 smoke data, showing that the smoke tends to increase with the fraction number. The regression equation for the HC emissions reflected this inverse relation with the boiling point distribution, as reflected in the T50 coefficient. T50 is the ASTM D 86 temperature at which 50 vol\% of a sample was distilled and collected. As indicated above, the regression equations for the smoke did not include boiling point information. They did indicate, however, that boiling point data could be used in lieu of some of the composition data to account for some variation of the smoke. The regression equation for the HC emissions is 


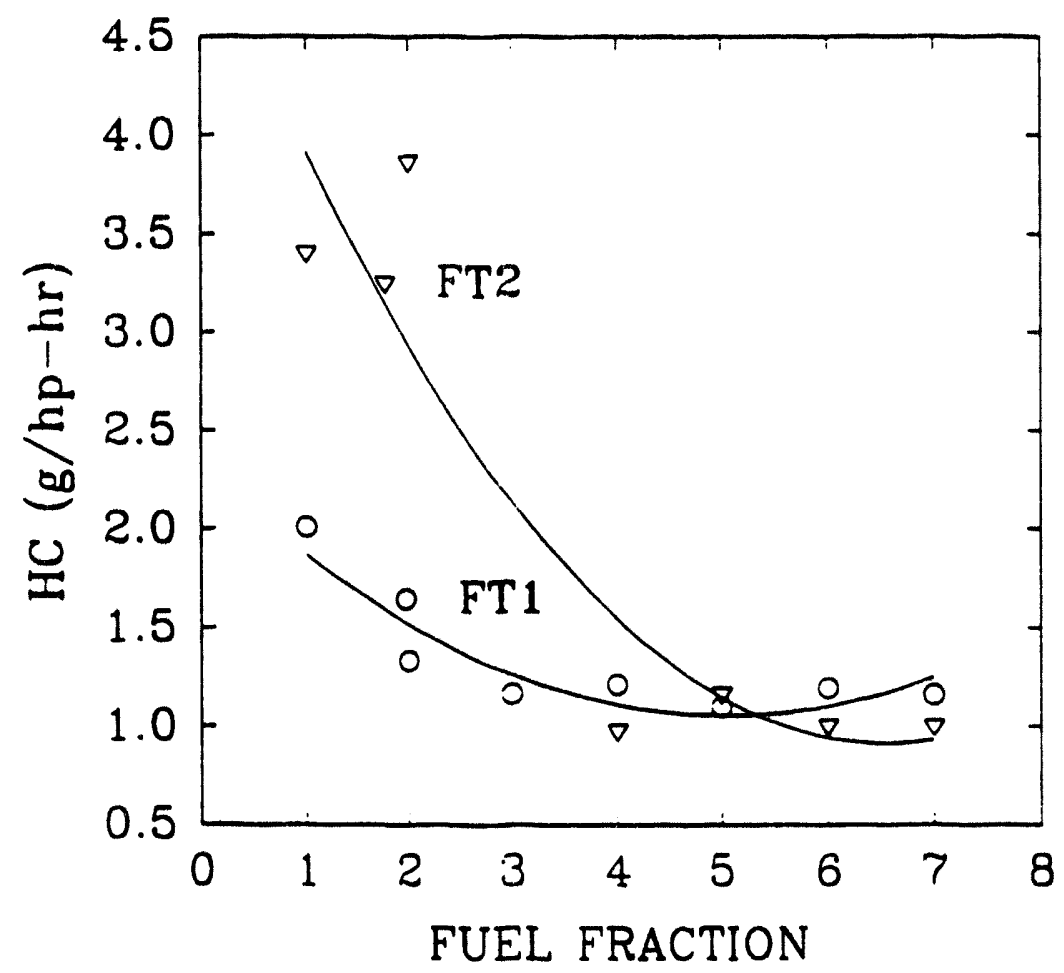

Figure 1. Hydrocarbon emissions versus fuel fraction for the Flscher-Tropsch fuels at Mode 2

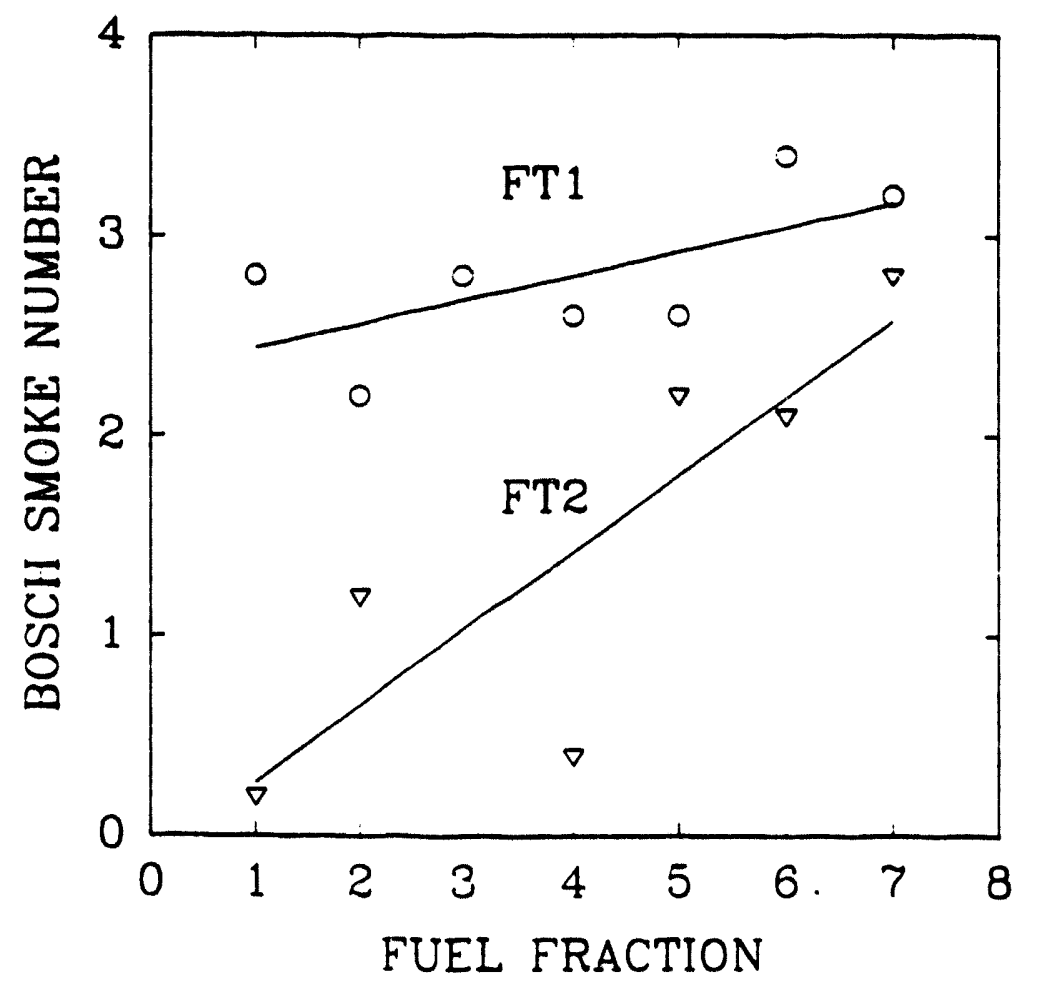

Figure 2. Bosch smoke number versus fuel fraction for the Fischer-Tropsch fuels at Mode 2 


$$
\begin{aligned}
& H C=A_{1}+A_{2} \times(\text { alkylbenzene })+A_{3} \times(\text { T50) } \\
& +A_{4} \times \text { (Indenes) }+A_{5} \times \text { (Monocycloparaffins) } \\
& +A_{6} \times \text { (Percent Carbon). } \\
& A_{1}=21.61 \quad R^{2}=0.83 \\
& A_{2}=0.095 \\
& A_{3}=-0.004 \\
& A_{4}=-0.15 \\
& A_{s}=0.029 \\
& \mathrm{~A}_{6}=-0.21
\end{aligned}
$$

The unbumed hydrocarbon emissions from diesel engines are dependent on both the physical processes that occur in the engine and the fuel properties that affect combustion efficiency. The physical processes include fuel atomization, vaporization, mixing and impingement. as well as quenching in the bulk gas because of over-rich or over-lean conditions, and thermal quenching in the boundary layers. These are all processes that result in incomplete burning. If the HC emissions are in fact dominated by the physical processes that lead to incomplete combustion, the properties that lead to increased soot production will likely produce reduced HC emissions. One possibility is that the total mass of unreacted carbon is accounted for in either the HC or the smoke emission, with the distribution also dependent on the conditions in the engine and the fuel properties.

The direct relationship between the $\mathrm{HC}$ and the alkylbenzene and the monocycloparaffins most probably reflects the stability of these structures relative to the other hydrocarbon groups. This is supported by the inverse relationship with the less stable indenes. The relationship to the wt \% carbon probably reflects the propensity of the fuels to form soot rather than HC.

\section{Cetane Number}

Preliminary stepwise regression analysis indicated that $89 \%$ of the variation in the $\mathrm{CN}$ in the test fuel matrix can be accounted for by the average boiling point and the specific gravity. The analysis also indicated that wt \% carbon and the concentration of alkyl groups associated with aromatic rings were directly related to the $\mathrm{CN}$ (12). These same relationships are reflected in the final regression equation, where

$$
\begin{aligned}
\mathrm{CN}=\mathrm{A}_{1} & \left.+A_{2} \times \text { (Alkylbenzene }\right)+A_{3} \times(\text { T50) } \\
& +A_{4} \times(\text { Indenes })+A_{5} \times(\text { Paraffins }) \\
& +A_{6} \times(\text { Specific Gravity })+A_{7} \times\left(\text { Viscosity @ } 40^{\circ} \mathrm{C}\right)
\end{aligned}
$$

and in which the concentrations are in wt \%, specific gravity is in $\mathrm{gm} / \mathrm{ml}$, and viscosity is in centistokes, and where

$$
\begin{aligned}
& A_{1}=277.1 \\
& A_{2}=0.54 \\
& A_{3}=0.31 \\
& A_{4}=-1.83 \\
& A_{5}=-0.13 \\
& A_{6}=-437.3 \\
& A_{7}=-1.98
\end{aligned}
$$


The direct relationship between the $\mathrm{CN}$ and the aromatic associated alkyl groups and boiling point information is consistent with the preliminary analysis. The inverse relationship with the viscosity is probably related to the effect on fuel atomization and evaporation, and the resulting influence on the physical aspects of the ignition delay time. The specific gravity effect is consistent with previous findings, as reflected in the correlations that are used to compute the cetane index. The inverse relationship with the indenes is consistent with the fact that the indenes have relatively high octane numbers, high autoignition temperature, and a correspondingly low $\mathrm{CN}$.

The inverse relationship of $\mathrm{CN}$ with the paraffins is, however, somewhat surprising in that the autoignition temperatures of the paraffins are generally low, and the corresponding CNs high, relative to the aromatic materials. It is possible that this effect of paraffin concentration may arise from the fact that hydroprocessing did not increase the paraffin concentration in all cases. The most noticeable case was the light cycle oil, where multicycles were converted to monocyclics and were then still aromatic. Hydroprocessing did, however, always increase the $\mathrm{CN}$ of any individual feedstock because of the increases in higher $\mathrm{CN}$ compounds including paraffins and cycloparaffins. The conversion process and distribution of products is dependent on the composition of the feedstock.

\section{Low Emission Fuels}

As first mentioned in a previous section. the low-emission fuels were formulated using linear programming techniques. The constraints on the properties and the compositions used in the calculations had to be chosen in several cases to meet the emissions requirements defined in terms of the EP. Recall that the EP was defined as a single numeric parameter representing the overall emissions performance of the fuels. The aromatic content and the CN data, presented in Table 7, are plotted in Figures 3 and 4, respectively, for the 10 low-emissions fuels. The target $\mathrm{CN}$ for Fuels 3,4, and 7 was $55 \mathrm{CN}$, while the aromatic content was to vary over a range of less than $10 \%$ to $30 \%$. The actual CNs for these fuels were in the range of 42 to 43 , and the aromatics were in the range of $1 \%$ to $30 \%$.

The target aromatic content for Fuels 5. 6, and 8 was $15 \%$ with the $\mathrm{CN}$ varying from 63 to $75 \mathrm{CN}$. The actual CNs of these fuels ranged from 30 to $60 \mathrm{CN}$, and the aromatic content varied from $8 \%$ to $15 \%$ because of limitations imposed by the composition of the available blending materials.

As indicated previously, these results demoristrate that the $\mathrm{CN}$ does not always blend linearly. The resulting fuels, although lower in $\mathrm{CN}$ thar, originally planned, do offer the oppornunity to study the effects of variation in aromatic content at neasty constant CN (Fuels, 3, 7, and 4 in order of increasing aromatic content), and the effects of variation in CN at nearly constant aromatic content (Fuels 5, 8, and 6 in order of decreasing $\mathrm{CN}$ ).

The Mode 2 condition was again selected for use in comparison of the low-emissions fuels. The Mode 2 NOx data for the 10 low-emissions fuels are presented in Figure 5. The corresponding data for the HC, CO, and smoke emissions are presented in Figures 6 through 8, respectively. The results in Figure 5 indicated a trend towards increased NOx emissions as the aromatic content is increased from $1 \%$ to $30 \%$. This can be seen by comparing data for Fuels 3 and 4 . In addition, the HC emissions appear to decrease, and the $\mathrm{CO}$ and smoke emissions increase with the increase in the aromatic content.

Increasing the $\mathrm{CN}$ from 30 to 60 , while holding aromatic content in the range of $8 \%$ to $15 \%$, results in a significant reduction in the NOx emissions. This variation in the $\mathrm{CN}$ results in a corresponding increase in the $\mathrm{HC}$, the $\mathrm{CO}$, and the smoke emissions.

Fuel 1 was designed to be the lowest emissions fuel that could be produced from the large number of potential blending materials that were available in this study. Although the NOx emissions of this fuel 


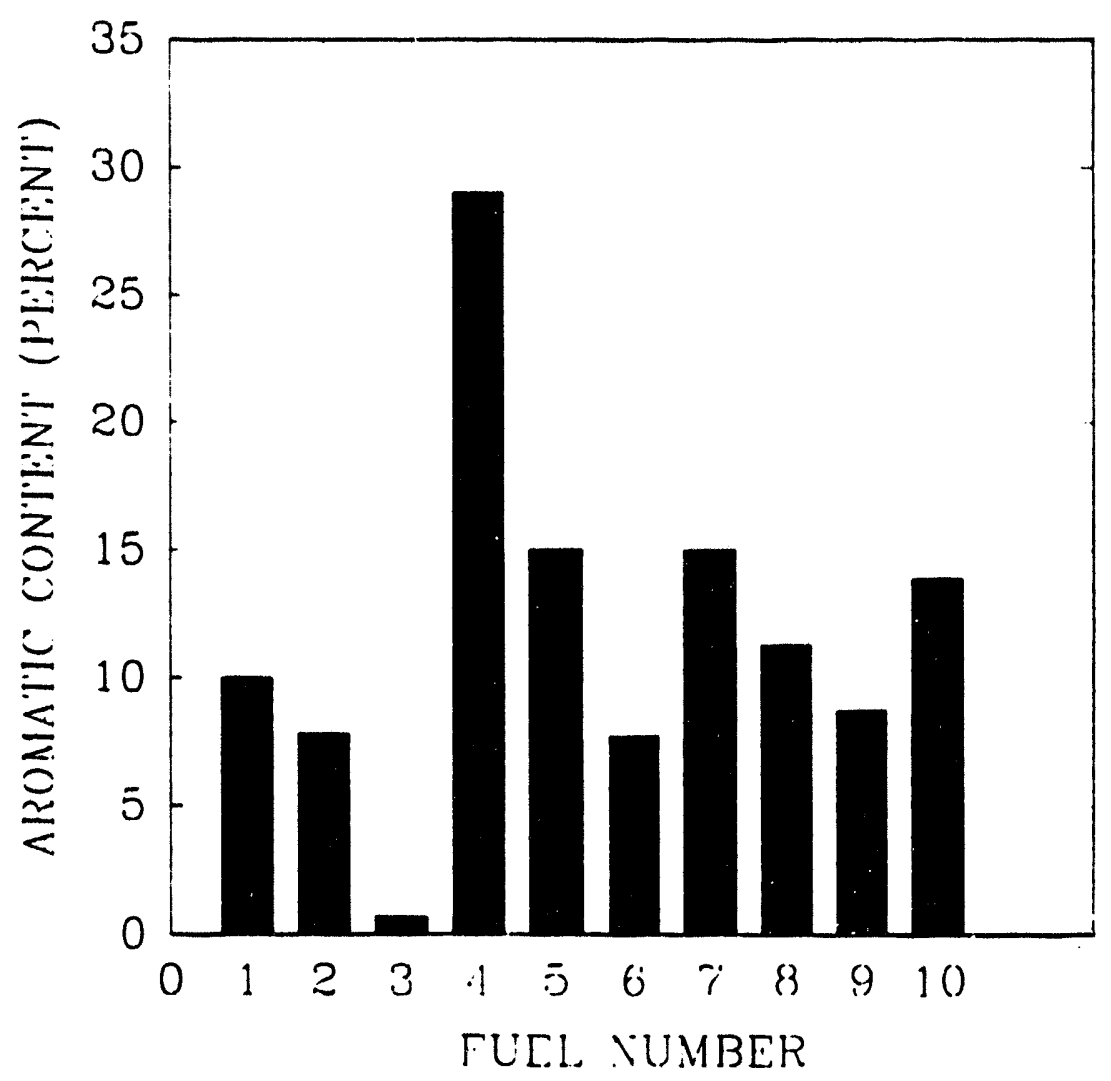

Figure 3. Aromatic content of the low-emissions fuels

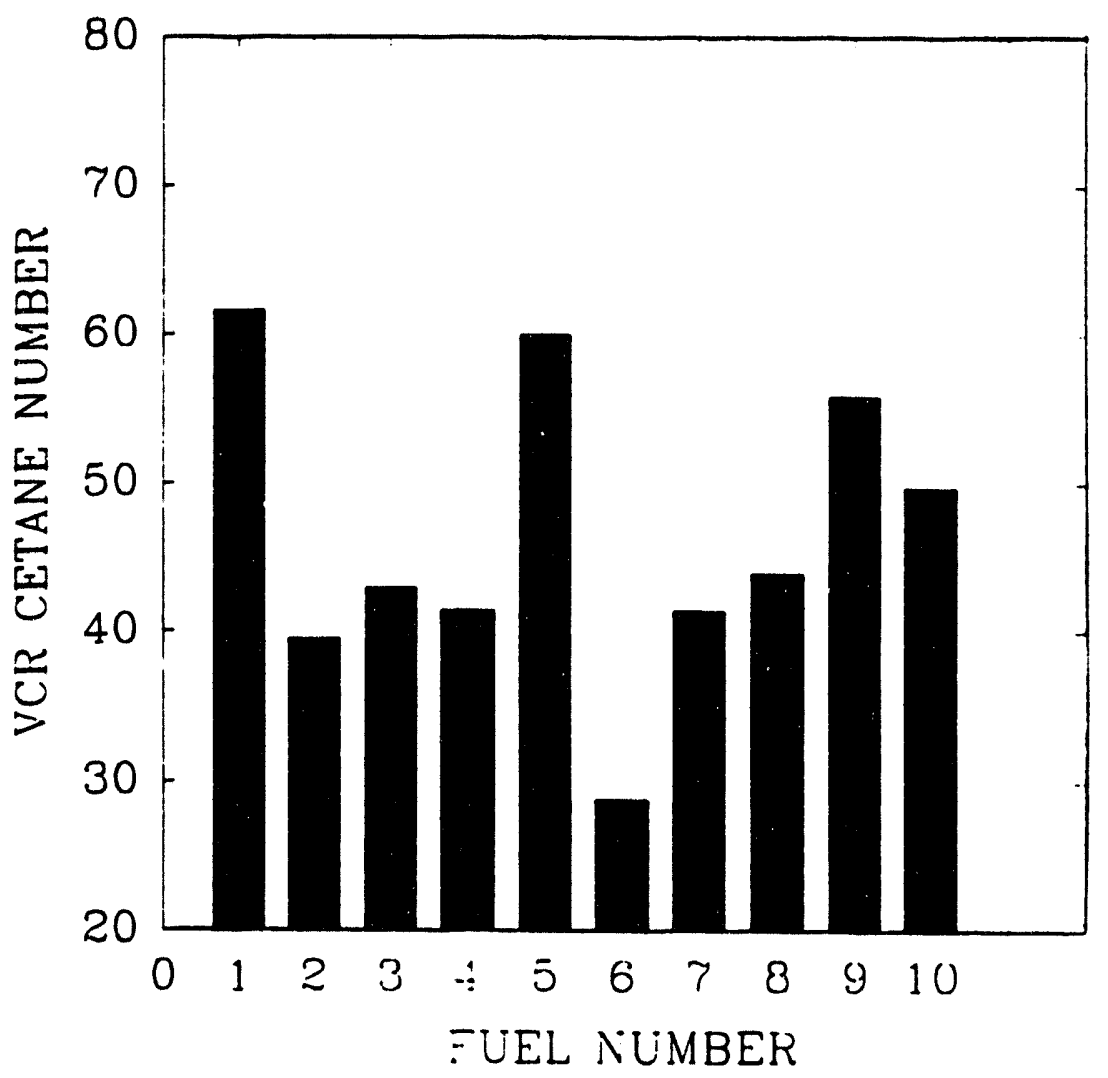

Figure 4. VCR cetane numbers of the low-emissions fuels 


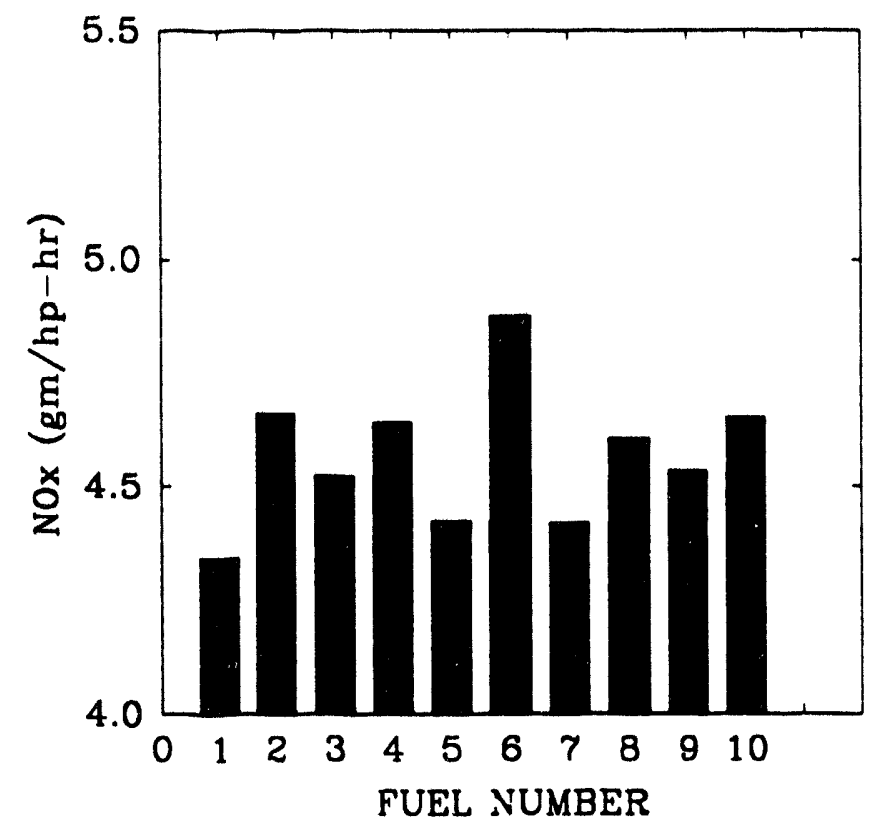

Flgure 5. NOx emissions for the low-emissions fuels at Mode 2

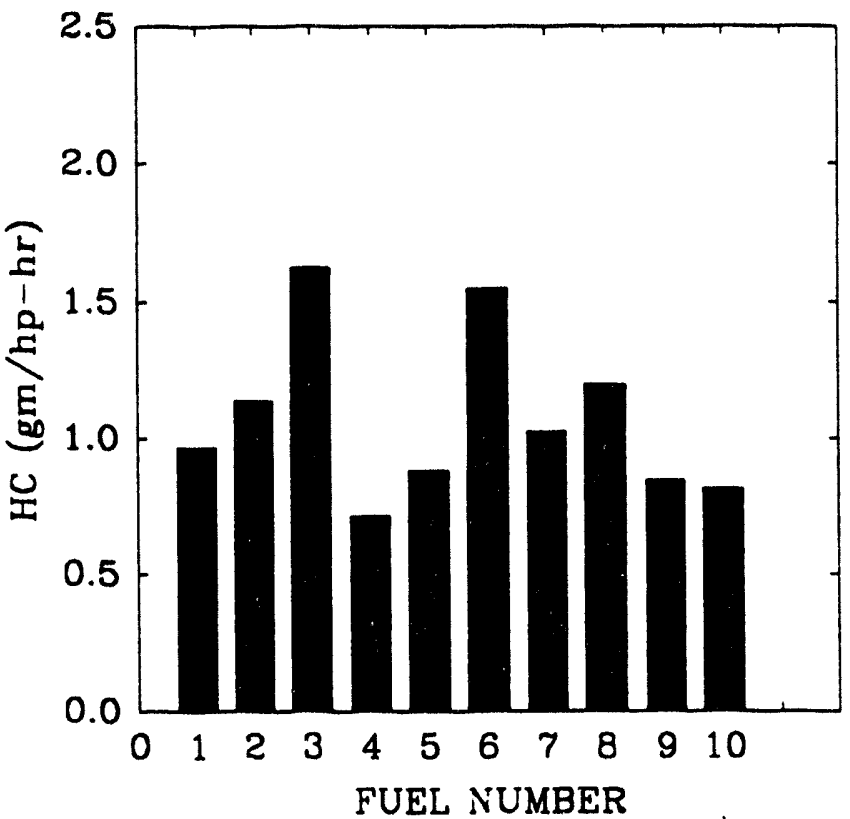

Figure 6. HC emissions for the low-emissions fuels at Mode 2 


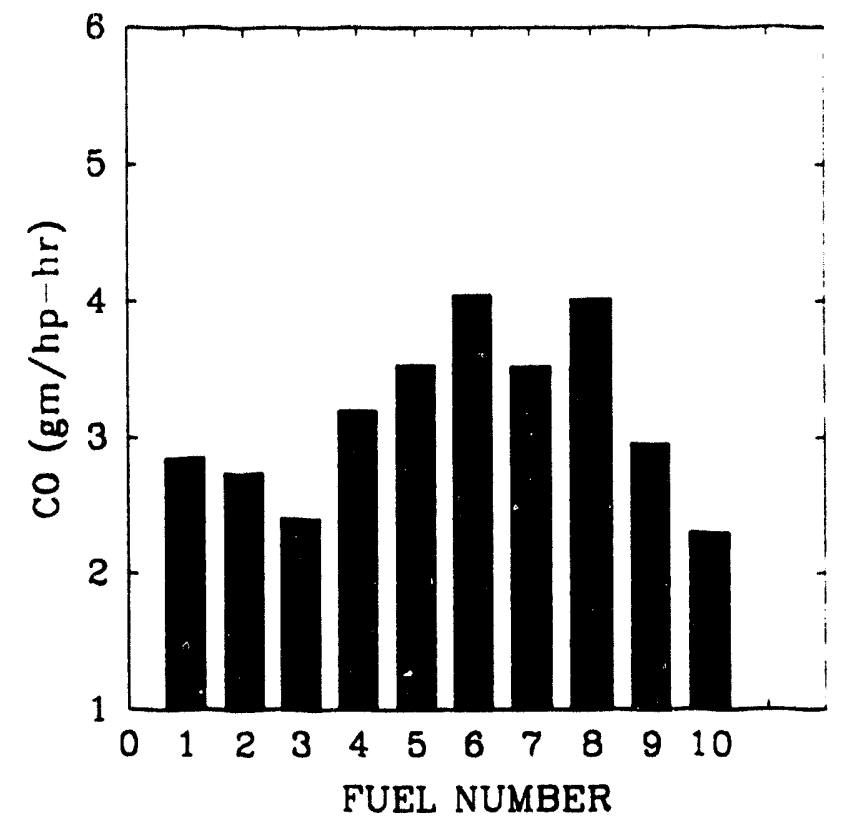

Figure 7. CO emissions for the low-emissions fuels at Mode 2

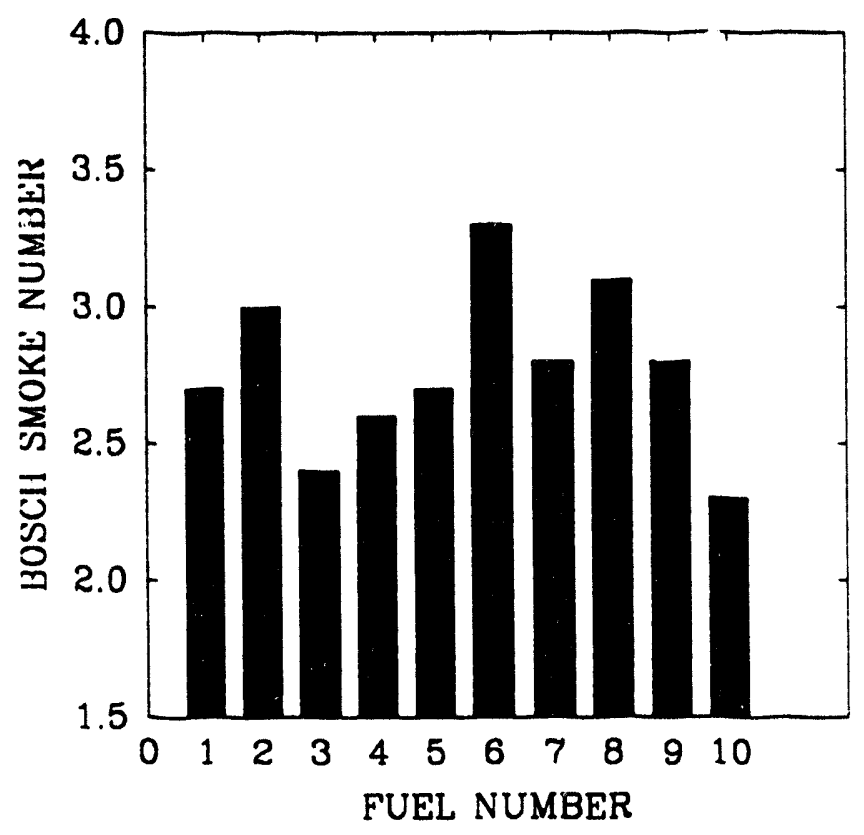

Figure 8. Bosch smoke numbers for the low-emissions fuels at Mode 2 
were clearly the lowest, other fuels had lower levels of the other emissions. This demonstrates the utility of using the EP for the fuel-to-fuel comparisons.

The EPs computed from the linear programming model and the actual values based on the measured emissions are presented in Figure 9 for the Mode 2 test condition. Several points can be made in examining the results presented in this figure. First, the predicted EP values are all very close to the target level of four. This is indicative of the results of the linear programming model, in which the EP was set as one of the constraints. The second point is the fact that the actual EPs follow the same trends as the predictions. This indicates that the basis of the modeling work is correct in a linear approximation. The same conclusion was also obtained in the detailed statustical analysis in which the relationships between the emissions and the fuel properties and composition are linear. The third observation is the fact that the actual EP values are significantly below the predicted and the target values in eight out of 10 cases, with the EPs averaging about 3.5. The EP values from all of the test materials examined in the test fuel matrix are plotted versus the average boiling points in Figure 10. The average of all the EPs is also indicated in the figure. As can be seen, the average Ep for the 80 fuels examined in this project was 4.3 at the Mode 2 test condition. The reduction from 4.3 to 3.5 indicates that full boiling range, low-emissions fuels can be designed and produced using actual blendstocks. Similar conclusions can be drawn from the data at the other test conditions, in which the EPs were generally below the target level of four, and well below the corresponding average EPs for all of the components. 


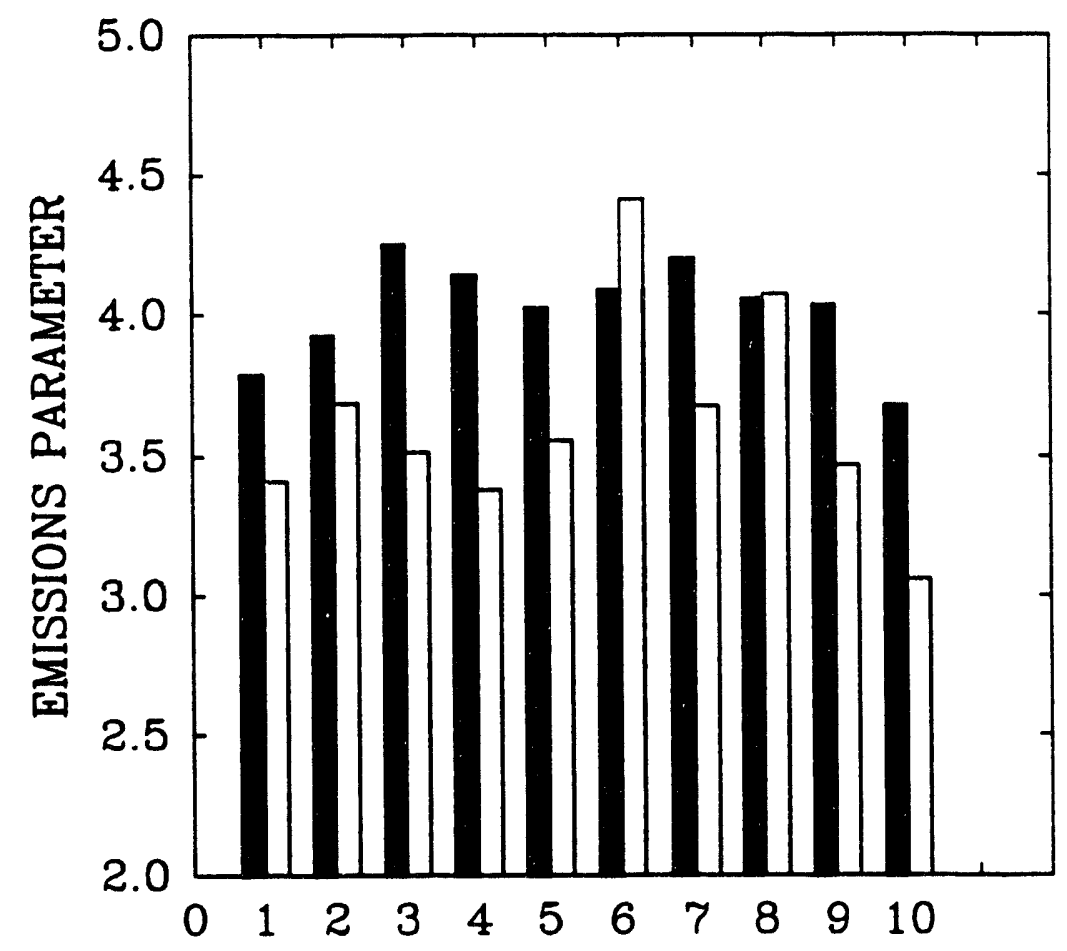

Figure 9. Emissions parameters for the low-emissions fuels at Mode 2

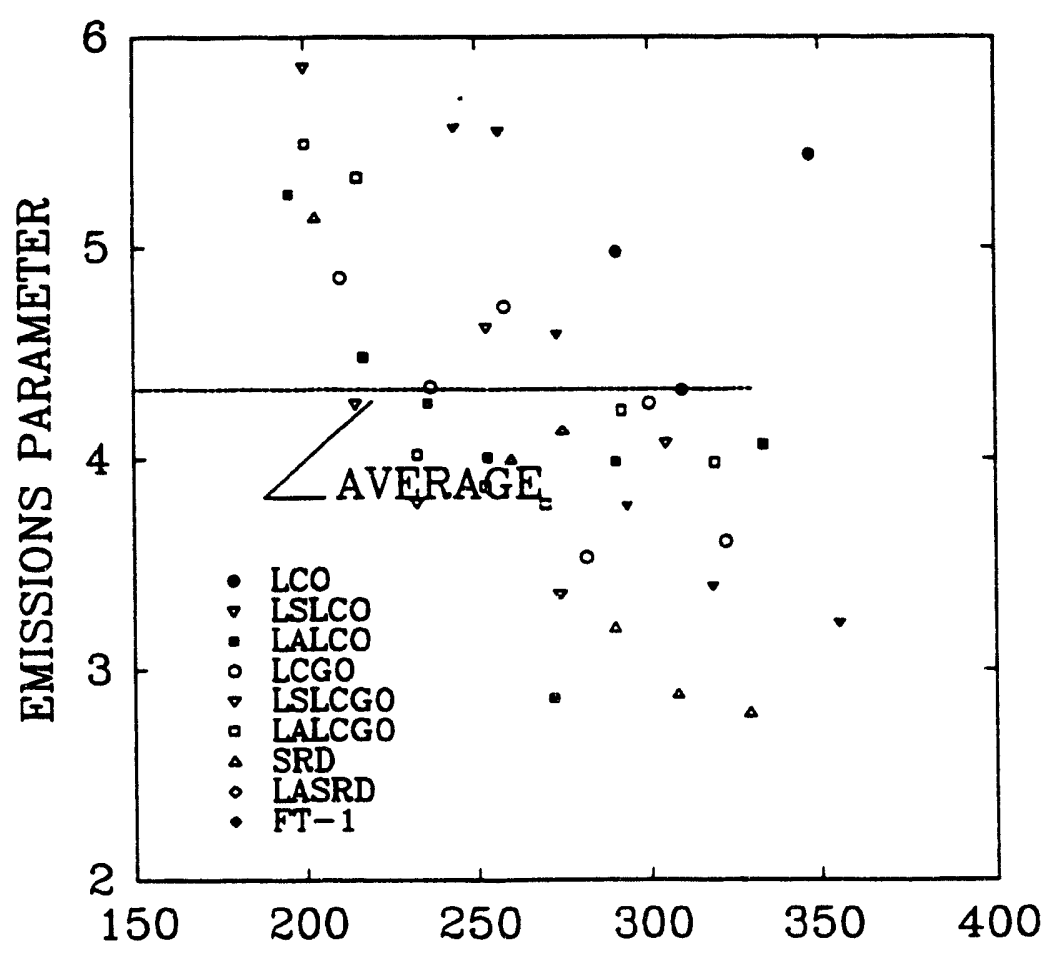

Figure 10. Emissions parameters for all test fuels at Mode 2 


\section{Summary and Conclusions}

The following are specific conclusions that can be drawn from the results of this task:

(1) The ignition quality and the emissions characteristics are related to the boiling point as indicated by the fact the strong functional relationships between these parameters and the average boiling point of each fraction.

(2) The ignition and emissions characteristics are directly related to the aromatic content and type of the fuel, with ignition quality reduced and the emissions increased as the aromatic content increases.

(3) Because of the relationship between the ignition quality and the aromatics, the variation of the emissions characteristic is accounted for in the aromatic description of the fuel and was therefore not found to be an important parameter in the regression equations.

(4) The relationships between the emissions and the fuel composition are linear within the range of this data set, so that linear programming techniques can be used to design low-emissions diesel fuels.

(5) Low-emissions diesel fuels can be formulated using blend stocks that can, on the average, be relatively high-emissions materials. Thi is accomplished by processing and blending to achieve the emissions and cost goals.

It is clear that further analyses could be made from the available test fuel matrix. The existing analysis showed substantial colinearity of several variables measured. Some of the unexpected results of the effect of various hydrocarbon types on the emission measurements must be viewed with the small range of the properties or the inherent experimental error in mind. The $80 \%-90 \%$ of the observed variability is accounted for in the correlation. In addition, the quantification of the dependence on type of aromatic compound is an important finding that will likely contribute to future reformulated diesel fuels. 


\section{Acknowledgments}

The authors would like to thank Dale Ott. Milan Maymar, and Jerry Chessher for their efforts in completing the combustion test. The efforts of Janet Buckingham and Bill Mason in completing the data analysis are also gratefully acknowledged. The financial and technical support of the U.S. Department of Energy and the National Renewable Energy Laboratory made this work possible. 


\section{References}

Asaumi, Y.: Shintani, M: Watanabe, Y. (October 1992). "Effects of Fuel Properties on Diesel Engine Exhaust Emission Characteristics." Prepared for the SAE International Fuels \& Lubricants Meeting \& Exposition, October 19-22, 1992. SAE Paper No. 922214. San Francisco, CA.

Bertoli, C.; Del Giacomo, N.; Iorio, B.; Prati, M.V. (October 1993). "The Influence of Fuel Composition on Particulate Emissions of DI Diesel Engines." Prepared for the SAE Fuels \& Lubricants Meeting \& Exposition, October 18-21, 1993. SP-994, SAE Paper No. 932733. Philadelphia. PA.

Betts, W.E.: Floysand. S.A.; Kvinge, F. (October 1992). "The Influence of Diesel Fuel Properties on Particulate Emissions in European Cars." Prepared for the SAE Intemational Fuels \& Lubricants Meeting \& Exposition, October 19-22, 1992. SAE Paper No. 922190. San Francisco, CA.

Burley, H.A.; Rosebrock, T.L. (October 1979). "Automotive Diesel Engines-Fuel Composition Versus Particulates." Prepared for the SAE Fuels \& Lubricants Meeting \& Exposition. October 18-21, 1979. SAE Paper 790923. Philadelphia, PA.

Cowley, L.T.; Doyon, J.; Stradling, R.J. (October 1993). "The Influence of Composition and Properties of Diesel Fuel on Particulate Emissions from Heavy-Duty Engines." Prepared for the SAE International Fuels \& Lubricants Meeting \& Exposition, October 18-21, 1993. SAE Paper 932732. Philadelphia. PA.

Erwin, J. (August 1992). "Assay of Diesel Fuel Component Properties and Performance." Prepared for the ACS Symposium on Synthetic Fuels, August 23-28. 1992. Washington, DC.

McCarthy, C.I.; Slodowske, W.J.; Sienicki, E.J.; Jass, R.E. (October 1992). "Diesel Fuel Property Effects on Exhaust Emissions from a Heavy Duty Diesel Engine that Meets 1994 Emissions Requirements." Prepared for the SAE International Fuels \& Lubricants Meeting \& Exposition, October 19-22, 1992. SAE Paper No. 922267. San Francisco, CA.

Miyamoto. N.; Ogawa, H.; Shibuya, M.; Suda, T. (October 1992). "Description of Diesel Emissions by Individual Fuel Properties." Prepared for the SAE Intemational Fuels \& Lubricants Meeting \& Exposition. October 19-22, 1992. SAE Paper No. 922221. San Francisco, CA.

Nikanjam, M. (March 1993). "Development of the First CARB Certified Califomia Altemative Diesel Fuel." Prepared for the SAE International Congress \& Exposition, March 1-5, 1993. SAE Paper No. 930728. Detroit, MI.

Palmer, H.B.; Curtis, C.F. (1965). "The Formation of Carbon from Gases." Chemistry and Physics of Carbon, P.L. Walker, 1st. Ed., Mercel Dekker, Inc., NY, 1965.

Ryan, T.W. III; Erwin, J. (October 1993). "Diesel Fuel Composition Effects on Ignition and Emissions." Prepared for the SAE International Fuels \& Lubricants Meeting \& Exposition. October 18-21, 1993. SAE Paper No. 932735. Philadelphia, PA.

Ryan, T.W. III; Erwin, J. (October 1992). "Effects of Fuel Properties and Composition on the Temperature Dependent Autoignition of Diesel Fuel Fractions." Prepared for the SAE International Fuels \& Lubricants Meeting \& Exposition, October 19-22, 1992. SAE Paper No. 922229. San Francisco, CA. 
Tosaka, S.; Fujiwara. Y.; Murayama, T. (February-March 1989). "The Effect of Fuel Properties on Diesel Engine Exhaust Particulate Formation." Prepared for the SAE International Congress \& Exposition. February 27 - March 3. 1989. SAE Paper No. 890421. Detroit, MI.

Uliman, T.L. (March 1989). "Investigation of the Effects of Fuel Composition, and Injection and Combustion System Type on Heavy-Duty Diesel Exhaust Emissions." Prepared for the Final Repor of the Coordinating Research Council, March 1989. CRC Contract CAPE-32-80, Project VE-1.

Ullman, T.L. (September 1989). "Investigation of the Effects of Fuel Composition, and Injection and Combustion System Type on Heavy-Duty Diesel Exhaust Emissions." Prepared for the SAE International Fuels \& Lubricants Meeting \& Exposition, September 25-28, 1989. SAE Paper No. 892072. Baltimore, MD.

Zeldovich, Ya. B. (1946) Acta Physiochem USSR 21 577-628. 
APPENDIX A

Diesol Fuel Aseay

\section{Blend Properties and Correlations}

\begin{tabular}{|c|c|c|c|c|c|c|c|c|c|c|}
\hline Fuel 10 & Blend it & Blend *2 & Blend 13 & Blend 4 & Blend is & Blend 16 & Blend : 7 & Blend :8 & Bland 49 & Biend 10 \\
\hline Acnaphthe & 0.268 & 0.335 & 0.055 & 4.723 & 2.396 & 1.350 & 2.389 & 1.878 & 1.064 & 0.209 \\
\hline Acnaphthy & 0.171 & 0.205 & 0.009 & 2.789 & 1.460 & 1.084 & 1.414 & 1.252 & 0.767 & 0.120 \\
\hline Alkbenz & 3.972 & 4.810 & 1.463 & 6.424 & 3.617 & 5.624 & 3.943 & 4.621 & 3.346 & 5.821 \\
\hline Alk_naph & 0.545 & 0.503 & 0.050 & 4.129 & 2.004 & 0.719 & 2.000 & 1.407 & 2.101 & 0.627 \\
\hline Arotrioy & 0.027 & 0.009 & 0.006 & 0.401 & 0.200 & 0.507 & 0.200 & 0.400 & 0.287 & 0.023 \\
\hline Aro_tol & 10.0 & 7.8 & 0.7 & 29.0 & 15.0 & 7.7 & 15.0 & 11.3 & 8.7 & 13.9 \\
\hline Indens & 3.500 & 4.206 & 0.77 & 2.645 & 1.394 & 3.516 & 1.711 & 2.450 & 2.082 & 4.771 \\
\hline Indenes & 2.076 & 2.053 & 0.250 & 1.801 & 0.850 & 1.187 & 1.000 & 1.073 & 1.604 & 2.954 \\
\hline Nephth & 0.019 & 0.000 & 0.000 & 0.134 & 0.068 & 0.021 & 0.087 & 0.044 & 0.086 & 0.067 \\
\hline nmrApp & 3.34 & 3.983 & 0.866 & 10.875 & 5.688 & 5.335 & 5.870 & 5.512 & 2.611 & 4.534 \\
\hline nmrAro & 1.625 & 1.783 & 1.240 & 6.657 & 3.654 & 2.811 & 3.948 & 3.283 & 2.012 & 1.878 \\
\hline nmrCh & 8.373 & 16.487 & 6.966 & 6.134 & 4.619 & 24.352 & 6.560 & 14.486 & 9.062 & 13.969 \\
\hline nmrChe & 50.453 & 42.695 & 52.487 & 49.918 & 56.218 & 30.721 & 51.202 & 43.469 & 53.369 & 45.039 \\
\hline nmrCh & 331.243 & 35.024 & 38.451 & 26.404 & 29.804 & 36.700 & 32.427 & 33.252 & 32.320 & 33252 \\
\hline Para & 59.149 & 39.331 & 80.838 & 64.239 & 75.041 & 15.979 & 72.539 & 45.510 & 60.577 & 45.412 \\
\hline Pan_di & 6.116 & 14.319 & 3.968 & 1.890 & 1.623 & 22.946 & 2.931 & 12.286 & 6.892 & 10.548 \\
\hline Pan_ti & 2.083 & 7.464 & 2.314 & 0.077 & 0.060 & 9.738 & 1.196 & 4.888 & 3.007 & 4.400 \\
\hline Par_mono & 17.073 & 26.668 & 10.245 & 10.648 & 11.007 & 37.250 & 10.447 & 24.128 & 17.472 & 23.657 \\
\hline Sal_tol & 84.395 & 87.744 & 97.352 & 76.877 & 87.713 & 85.605 & 87.114 & 86.804 & 87.966 & 83995 \\
\hline SpCr & 0.774 & 0.842 & 0.781 & 0.843 & 0.816 & 0.872 & 0.812 & 0.84 & 0.816 & 0.824 \\
\hline TotalUV & 3.417 & 4.080 & 0.838 & 13.524 & 6.917 & 6.122 & 7.181 & 6.520 & 4.329 & 444 \\
\hline T50 & 406.520 & 504.300 & 437.201 & 544.305 & 546.094 & 475.032 & 490.753 & 510.563 & 527.335 & 509294 \\
\hline UVdi & 0.686 & 0.730 & 0.075 & 6.722 & 3.400 & 1.568 & 3.390 & 2.460 & 1.790 & 0.765 \\
\hline UVmono & 2.725 & 3.351 & 0.763 & 5.880 & 3.041 & 3.797 & 3.322 & 3.419 & 2.178 & 3.672 \\
\hline UVtri & 0.000 & 0.000 & 0.000 & 0.988 & 0.476 & 0.761 & 0.460 & 0.619 & 0.350 & 0.000 \\
\hline Vis40 & 3.031 & 3.142 & 2.040 & 3.708 & 3.688 & 2.904 & 2.874 & 3.256 & 3.321 & 3.150 \\
\hline Vis 100 & 1.169 & 1.220 & 0.894 & 1.356 & 1.352 & 1.147 & 1.115 & 1.250 & 1.278 & 1.200 \\
\hline VParom & 14.721 & 14.440 & 10.264 & 35.700 & 23.434 & 15.906 & 22.982 & 19.715 & 15.239 & 13.782 \\
\hline VPolel & 4.043 & 2.586 & 4.891 & 4.255 & 5.221 & 0.845 & 4.573 & 3.003 & 3.721 & 1.624 \\
\hline VPsat & 76.268 & 82.940 & 84.886 & 60.054 & 71.349 & 83.127 & 72.470 & 7.238 & 80.226 & 83229 \\
\hline WIPC & 81.488 & 86.257 & 85.043 & 86.725 & 85.887 & 86.937 & 85.884 & 86.412 & 85.392 & 85.062 \\
\hline WIPH & 13.663 & 13.670 & 14.851 & 13.475 & 14.254 & 12.924 & 14.213 & 13.589 & 14.033 & 13.711 \\
\hline WIPS & 0.012 & 0.009 & 0.001 & 0.005 & 0.004 & 0.004 & 0.003 & 0.004 & 0.017 & 0.000 \\
\hline
\end{tabular}


APPENDX $\mathrm{B}$

Varieble Definilions

\begin{tabular}{|c|c|c|c|}
\hline VARIABLE NAMES & DESCAIPTIONS & DEscAIPTIONS & DESCRIPTIONS \\
\hline ACNAPTHE & Acenaphthenes & NDOTF & Fuol Flow Rate \\
\hline ACNAPTHY & Acenaphthylenes & NAPHTH & Naphthalene \\
\hline AFEPA & Air-Fuol Ratio (EPA) & NMPALP & NMR Parameter \\
\hline AFERR & $\begin{array}{l}\text { Alr-FurfRatio } \\
\text { (ERिOA) }\end{array}$ & NMRARO & NMA Parameter \\
\hline AFHEY & $\begin{array}{l}\text { Air-Fuel Ratio } \\
\text { (Heywood) }\end{array}$ & NMACH & NMR Paramoter \\
\hline AFLOW & Air-Flow & NMACH2 & NMA Paramoter \\
\hline AFR & $\begin{array}{l}\text { Air.Fupl Ratio } \\
\text { (Mass) }\end{array}$ & NMRCH3 & NMA Paramotor \\
\hline AFrs & $\begin{array}{l}\text { Air.Fugl Rgtio } \\
\text { (Emissions) }\end{array}$ & PARA & Paraffins \\
\hline AFSPDT & $\begin{array}{l}\text { Air-fupl Ratio } \\
\text { (Splndt Eq.) }\end{array}$ & PARA_DI & Dicycloparatifins \\
\hline ALKBENZ & Alky Benzene & PARA_TRI & Trloyeloperafifins \\
\hline ALK_NAPH & Alkyl Naphthalanos & PAR_MONO & Monocycloparaffins \\
\hline API & API Gravity & PHIHEY & Equivalenco Ratio (Heywood) \\
\hline APMAX & Anglo of $P \max$ & PHISPOT & Equivalence Ratio (Spindt) \\
\hline AQMAX & Angle of Omax & PMWX & Peak Combustion Pressure \\
\hline AROTRICY & Trioyclio Aromatic & OIN & Enorgy Input \\
\hline ARO_TOT & Total Aromatio & amax & Peak Heat-Release Rate \\
\hline sco & Brake-Specific Co & QR & Apparent Combustion Efficiency \\
\hline BHC & Brake-Spocific HC & QTOT & Cumulative Hoat Roloase \\
\hline BHP & Brake Power & SAT_TOT & Total Saturates \\
\hline BKNOX & Brake-Specific NOX & SMOKE & Bosch Smoke \\
\hline BOI & Beginning of & SPGR & Spodfic Gravity \\
\hline BPAVG & Ayerege Boiling & T10 & Temperature at $10 \%$ \\
\hline BTE & $\begin{array}{l}\text { Brake Thermal } \\
\text { Eficioncy }\end{array}$ & T30 & $30 \%$ \\
\hline CAABON & Fuel Carbon & T50 & $50 \%$ \\
\hline ClD976 & $\begin{array}{l}\text { Cotane lnod } x \\
\text { (Asim 976) }\end{array}$ & T70 & $70 \%$ \\
\hline ClD 4734 & $\begin{array}{l}\text { Cotane Index } \\
\text { (Astint434) }\end{array}$ & T90 & $90 \%$ \\
\hline $\mathrm{CN}$ & Getan Number & T95 & $95 \%$ \\
\hline CVCA & $\begin{array}{l}\text { Cotane Number } \\
\text { (CVA) }\end{array}$ & TIN & Intake Air Temperature \\
\hline EP & End Point & TOTALUV & UV Aromatic \\
\hline FFLOW & Fuel Flow & UVDI & UV Dicyclic Aromatic \\
\hline FHP & Friction Power & UVMONO & UV Monocyclic Aromatic \\
\hline FLNUM & Fuel Number & UVTRI & UV Tricydic Aromatic \\
\hline FRAC & $\begin{array}{l}\text { Fuel Fraction } \\
\text { Number }\end{array}$ & VIS4O & Viscosity at $40^{\circ} \mathrm{C}$ \\
\hline FUEL & Fuol Name & VIS100 & Viscosity at $100^{\circ} \mathrm{C}$ \\
\hline HV & Heating Value & VPAROM & Volume Percent Aromatic \\
\hline HYDROGEN & Fual Hychogen & VPOLEF & Volume Percent Olefin \\
\hline IBP & Initial Boiling Point & VPSAT & Volume Percent Saturate \\
\hline INDANS & Indanes & WTPC & Weight Percent Carbon \\
\hline INDENES & Indenes & WTKPH & Weight Percent Hydrogen \\
\hline MAP & Manifold Pressuro & WTPS & Weight Percent Sultur \\
\hline
\end{tabular}




\section{APPENDIX C}

Propertice of Base Fuels and Distillation Fractions

C-1 


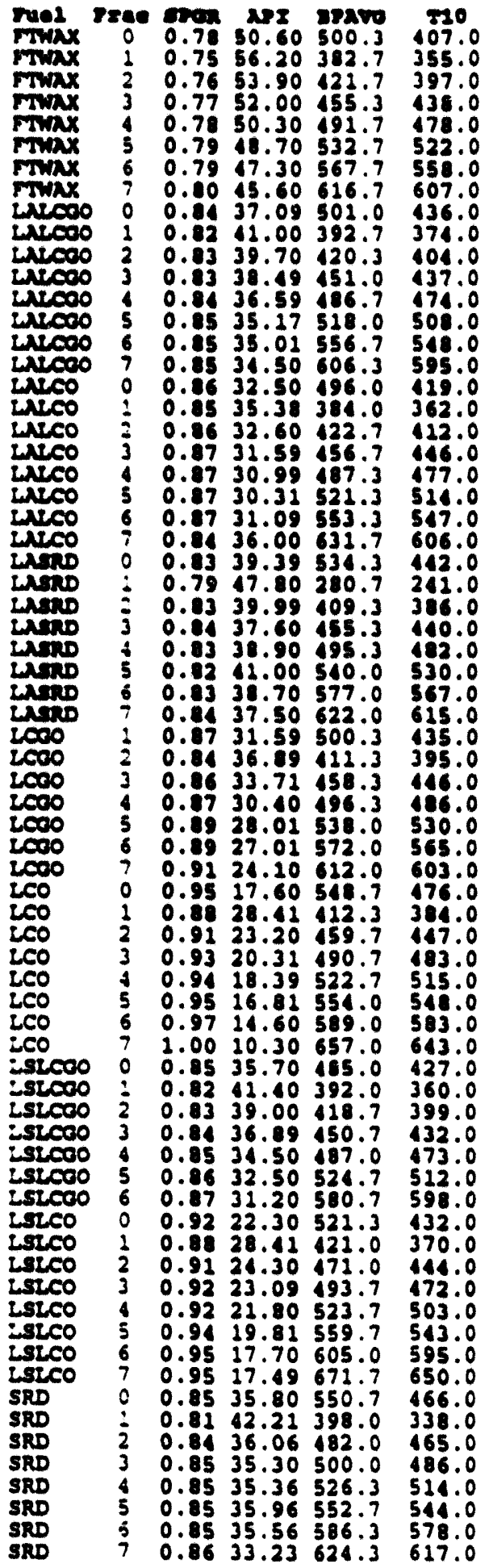

200

$449.0-530$ $362.0 \quad 373.0$ $104.0 \quad 416.0$

$141.0 \quad 153.0$

$185.0 \quad 490.0$

526.0531 .0

$562.0 \quad 566.0$

611.0615 .0

164.0491 .0

$382.0 \quad 390.0$

$442.0 \quad 448.0$

$179.0 \quad 483.0$

$512.0 \quad 516.0$

$552.0 \quad 556.0$

599.0602 .0

119.0

372.0384 .0

$116.0 \quad \$ 22.0$

$450.0 \quad 454.0$

$182.0 \quad 186.0$

517.0

550.0

613.0

258.0

396.0

445.0

189.0

534.0

573.0

518.0257 .0

$162.0 \quad 192.0$

$403.0 \quad 410.0$

$451.0 \quad 456.0$

$191.0 \quad 195.0$

$533.0 \quad 537.0$

569.0571 .0

606.0609 .0

$509.0 \quad 536.0$

$397.0 \quad 410.0$

$155.0 \quad 459.0$

486.0490 .0

$\begin{array}{ll}518.0 & 522.0 \\ 550.0 & 552.0\end{array}$

$\begin{array}{ll}550.0 & 552.0 \\ 586.0 & 588.0\end{array}$

645.0651 .0

$454.0 \quad 476.0$

$374.0 \quad 389.0$

$407.0 \quad 415.0$

$439.0 \quad 47.0$

$478.0 \quad 484.0$

$\begin{array}{ll}518.0 & 523.0 \\ 572.0 & 577.0\end{array}$

$572.0 \quad 577.0$
$491.0 \quad 518.0$

$103.0 \quad 124.0$

$456.0 \quad 467.0$

$478.0 \quad 488.0$

$510.0 \quad 519.0$

$549.0 \quad 537.0$

$\begin{array}{ll}599.0 & 603.0 \\ 655.0 & 663.0\end{array}$

$655.0 \quad 663.0$

$377.0 \quad 404$.

$473.0 \quad 480.0$

$492.0 \quad 498.0$

$518.0 \quad 523.0$

581.0584 .0

620.0
200

592.0
120.0

452.0

475.0

507.0

545.0

628.0

576.0

414.0

440.0

503.0

530.0

566.0

622.0

106.0

434.0

170.0

199.0

530.0

561.0

622.0

323.0

438.0

174.0

510.0

587.0

631.0

574.0

429.0

173.0

508.0
547.0

547.0
500.0

624.0

634.0

443.0

473.0

531.0

562.0

596.0

677.0

552.0

427.0

173.0

504.0

539.0
567.0

567.0
614.0

469.0

502.0

521.0

579.0

617.0

702.0

635.0

501.0

516.0

542.0

564.0

634.0
27 verte vis 100

$\begin{array}{llll}620.0 & 18876 & \vdots .42 & 1.05 \\ 456.0 & 18095 & \vdots .16 & 0.62\end{array}$

$474.018953: .40 \quad 0.74$

$188.018875 \quad: .85 \quad 0.86$

$521.0 \quad 10888 \quad: .37 \quad 1.02$

$557.010887 \div .11 \quad 1.24$

$589.018065 \quad \div .01 \quad 1.46$

$638.010901 \quad 3.71 \quad 1.88$

$\begin{array}{llll}612.0 & 10562 & 2.67 & 1.10\end{array}$

$430.018556 \quad: .35 \quad 0.69$

$466.010561 \div .58 \quad 0.78$

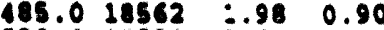

$20.018539 \div .61 \quad 1.08$

$546.018523 \quad 3.37 \quad 1.28$

$574.018547 \quad \$ .63 \quad 1.55$

057.07972

$19.018412 \div 33 \quad 0.70$

$153.018401 \quad: .750 .84$

$188.018390 \quad \vdots .27 \quad 1.22$

$14.018390 \quad 2.71 \quad 1.12$

$14.018422 \quad 3.50 \quad 1.32$

$574.018452 \div .47 \quad 1.54$

$715.018646 \quad .22 \quad 2.15$

$664.018650 \quad 3.77 \quad 1.29$

$\begin{array}{llll}351.018461 & \vdots .75 \quad 0.45\end{array}$

$\begin{array}{lllll}45.0 & 18524 & \vdots .53 & 0.75\end{array}$

$180.018512 \quad \vdots .22 \quad 0.96$

$526.010592 \quad 3.81 \quad 1.16$

$562.018690 \quad 3.46 \quad 1.32$

$97.010675 \quad i .351 .58$

641.018680 ¿.09 1.9

$608.018257=.561 .10$

$\begin{array}{llll}461.0 & 18371 \quad: .46 & 0.73\end{array}$

$491.018342=.210 .90$

$526.018279 \quad \equiv .77 \quad 1.12$

$565.018342 \quad 3.97 \quad 1.90$

$595.018247 \quad \Xi .64 \quad 1.68$

$\begin{array}{lll}64.0 & 18329 & 16.08 \quad 2.40\end{array}$

$689.017900 \quad 3.16 \quad 1.20$

$460.017943 \quad \div .550 .65$

$492.017928 \quad: .30 .81$

$418.017893=.240 .94$

$544.017871 \quad \therefore .78 \quad 1.09$

$575.017868 \quad 3.74 \quad 1.31$

$614.017842 \leqq .47 \quad 1.64$

$734.0 \quad 17781 \quad 2 . .38 \quad 2.40$

$590.018430=.31$

$\begin{array}{llll}47.0 & 18486 & \vdots=6 & 0.58\end{array}$

$467.018461 \quad: .52 \quad 0.76$

$492.018441 \quad: .30 \quad 0.87$

$526.018409=3.52 \quad 1.06$

$550.018386 \quad 3.45 \quad 1.30$

$624.018418 \quad \Xi .31 \quad 1.58$

$682.017991 \div .36 \quad 1.16$

$510.017996 \quad: .39 \quad 0.70$

$544.017967 \div .390 .88$

$548.017963 \div .340 .99$

$572.017972 \quad 2.55 \quad 1.02$

$595.017963 ;.: 1 \quad 1.39$

$630.017957 \quad \hat{\epsilon} .41 \quad 1.85$

$738.018171: 3.37 \quad 2.89$

672.018528 j.

$\begin{array}{llll}45.0 & 18502 \quad: .26 & 0.58\end{array}$

$515.018457 \quad=.280 .99$

$529.018456 \div .30 \quad 1.10$

$556.018485 \quad \vdots .28 \quad 1.25$

$576.018535+.351 .42$

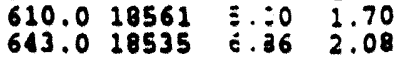




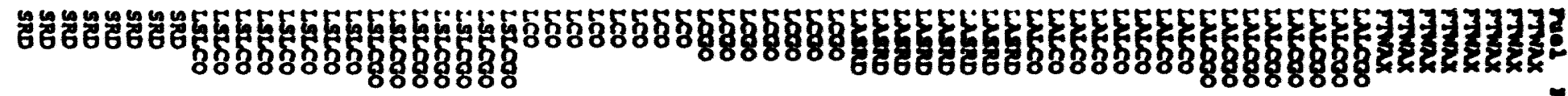

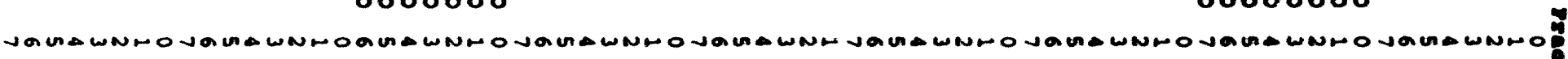

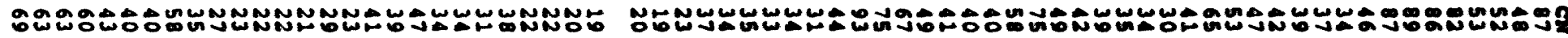

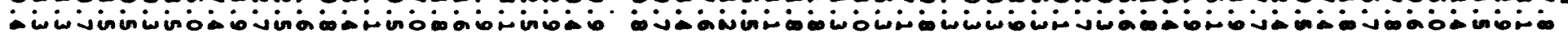

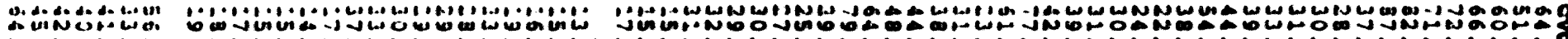

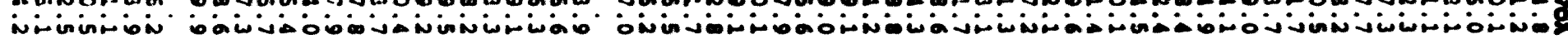

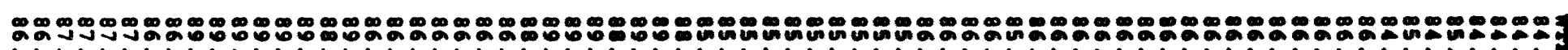

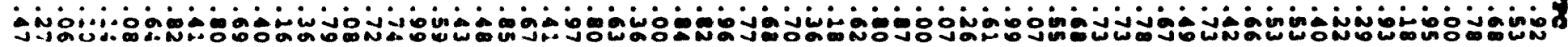

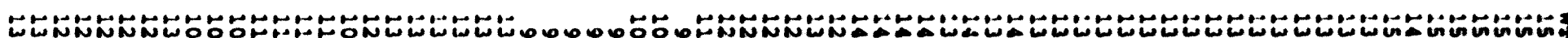
ڤnond

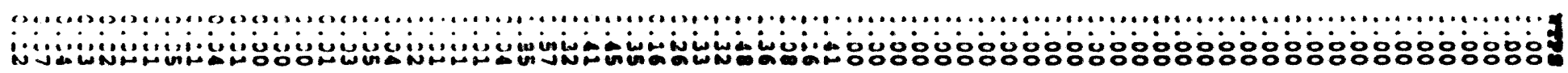

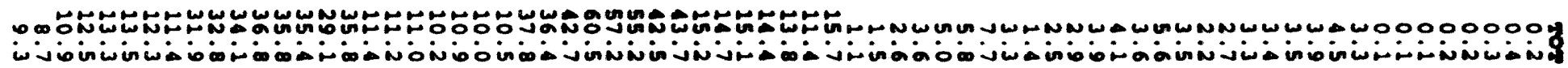
WW A-AA NANGF⿱艹

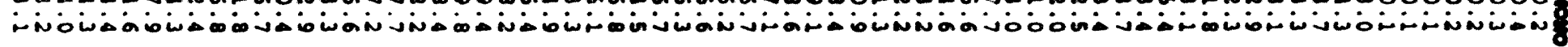

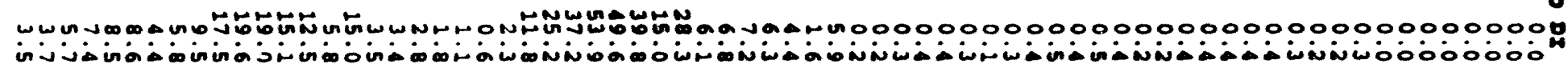

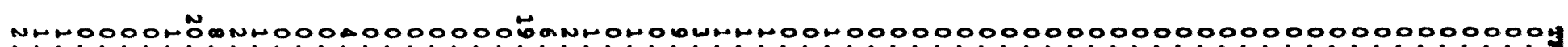

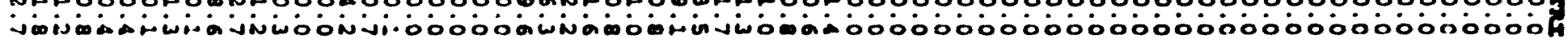

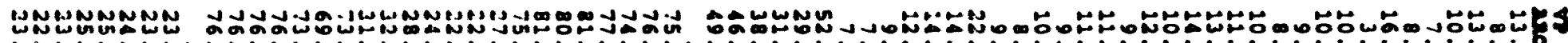

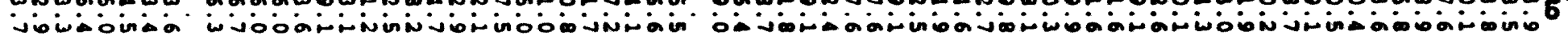

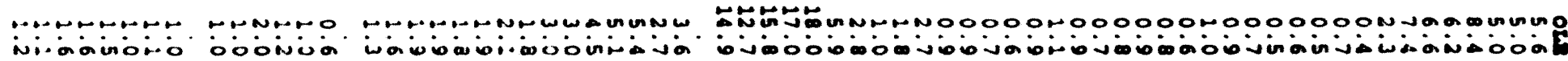

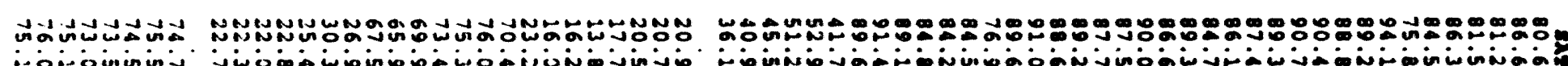


TASK 3 Test Fuel Compostlions and Components

\section{D-1}




\begin{tabular}{|c|c|c|c|c|c|c|c|c|c|c|}
\hline \multicolumn{11}{|c|}{ COMPOSITION OF TASK 3 BLENDS, WEMGHT FAACTION OF COMPONENTS } \\
\hline \multirow[t]{2}{*}{ COMP. ID } & \multicolumn{10}{|c|}{ BLEND NUMBER } \\
\hline & 1 & 2 & 3 & 4 & 5 & 6 & 7 & 8 & 9 & 10 \\
\hline$W_{13}$ & NA & N/A & 0.7334 & N/A & NA & NA & 0.3667 & N/A & NA & N/A \\
\hline W44 & 0.1268 & 0.0700 & NA & 0.0942 & 0.1390 & NA & 0.0471 & 0.0695 & 0.1326 & NiA \\
\hline W56 & 0.3141 & 0.1735 & 0.0493 & 0.4131 & 0.5419 & NA & 0.2312 & 0.2710 & 0.3284 & 0.5421 \\
\hline W77 & N/A & N/A & 0.0303 & 0.1104 & 0.1252 & NA & 0.0704 & 0.0626 & N/A & N/A \\
\hline AD46 & 0.1879 & 0.0012 & NA & N/A & N/A & NA & NA & N/A & 0.0241 & NA \\
\hline AD77 & 0.0518 & 0.0003 & NA & N/A & NA & N/A & NA & NA & 0.0066 & 0.0142 \\
\hline AD88 & 0.0498 & 0.0003 & N/A & N/A & N/A & NA & N/A & NA & 0.0064 & 0.0136 \\
\hline AG36 & N/A & N/A & NA & $N / A$ & NA & NA & N/A & NA & N/A & 0.2004 \\
\hline SC34 & N/A & N/A & N/A & 0.2317 & 0.1175 & NA & 0.1159 & 0.0588 & N/A & NA \\
\hline SC56 & N/A & N/A & NA & 0.1506 & 0.0764 & 0.0534 & 0.0753 & 0.0649 & N/A & NA \\
\hline SC77 & NA & N/A & NA & N/A & N/A & 0.0242 & NA & 0.0121 & N/A & NA \\
\hline AC11 & N/A & N/A & N/A & N/A & NA & 0.1283 & NA & 0.0642 & NA & N/A \\
\hline AC25 & N/A & 0.4186 & 0.1477 & N/A & NA & 0.7941 & 0.0739 & 0.3971 & 0.1422 & N/A \\
\hline AC67 & N/A & 0.1113 & 0.0393 & NA & NA & NA & 0.0197 & NA & 0.0378 & NAA \\
\hline SRD & N/A & NA & NA & N/A & NA & NA & NA & N/A & 0.2769 & N/A \\
\hline LSLCGO & 0.2696 & 0.2248 & N/A & $N / A$ & NA & NA & NA & NA & 0.0450 & 0.2297 \\
\hline TOTAL & 1.0000 & 1.0000 & 1.0000 & 1.0000 & 1.0000 & 1.0000 & 1.0000 & 1.0000 & 1.0000 & 1.0000 \\
\hline
\end{tabular}

N/A = Not applicable 


\begin{tabular}{|c|c|c|c|c|c|c|c|c|c|}
\hline \multicolumn{10}{|c|}{ COMPOSITION AND CALCULATED CETANE OF DISTLLED BLEND COMPONENTS FOR TASK 3 TEST FUELS } \\
\hline COMP. ID & $\begin{array}{l}\text { INCLUDED } \\
\text { DISTILLATION } \\
\text { CUTS } \\
\text { FUEL, CUT } \\
\text { NOS. }\end{array}$ & $\begin{array}{l}\text { DISTILLATION } \\
\text { YIELD \% } \\
\text { PARENT }\end{array}$ & $\begin{array}{l}\text { SPECIFIC } \\
\text { GRAVITY }\end{array}$ & WT\% C & WT\% H & $\begin{array}{c}\text { VOL\% } \\
\text { AROMATICS } \\
\end{array}$ & $\begin{array}{c}\text { SULFUR, } \\
\text { PPM }\end{array}$ & CVCA & CN \\
\hline W13 & FTWAX, 1-3 & 42.5 & 0.7609 & 84.58 & 15.42 & 0.2 & 18 & 57.4 & 50.8 \\
\hline W44 & FTWAX, 4 & 11.5 & 0.7783 & 85.00 & 15.00 & 0.2 & 30 & 72.1 & 82.4 \\
\hline W56 & FTWAX, 5-6 & 28.5 & 0.7886 & 85.08 & 14.92 & 0.2 & 15 & 77.2 & 88.0 \\
\hline W77 & FTWAX, 7 & 17.5 & 0.7990 & 84.93 & 15.07 & 0.2 & 10 & 87.3 & 87.3 \\
\hline AD46 & LASRD, 4-6 & 49.0 & 0.8273 & 85.70 & 14.30 & 9.6 & 10 & 52.9 & 64.7 \\
\hline AD77 & LASRD, 7 & 13.5 & 0.8373 & 85.62 & 14.38 & 7.6 & 10 & 79.1 & 93.0 \\
\hline AD88 & LASRD, 8 & 13.0 & 0.8408 & 85.65 & 14.35 & 6.0 & 12 & 82.0 & 93.0 \\
\hline AG36 & LALCGO, 3-6 & 49.4 & 0.8424 & 86.57 & 13.43 & 10.7 & 12 & 36.5 & 45.1 \\
\hline SC34 & LSLCO, 3-4 & 37.0 & 0.9188 & 88.95 & 11.05 & 76.0 & 34 & 16.4 & 22.6 \\
\hline SC56 & LSLCO, 5-6 & 24.1 & 0.9407 & 89.36 & 10.64 & 76.5 & 52 & 19.1 & 25.4 \\
\hline SC77 & LSLCO, 7 & 10.9 & 0.9497 & 89.03 & 10.86 & 75.0 & 1140 & 26.4 & 35.0 \\
\hline $\mathrm{AC} 11$ & LALCO, 1 & 11.3 & 0.8479 & 86.81 & 13.19 & 12.6 & 10 & 22.4 & 30.4 \\
\hline$A C 25$ & LALCO, 2-5* & 70.1 & 0.8691 & 86.43 & 13.57 & 10.7 & 10 & 32.2 & 38.9 \\
\hline AC67 & LALCO, 6-7* & 18.6 & 0.8533 & 85.96 & 14.04 & 8.7 & 10 & 47.9 & 57.6 \\
\hline
\end{tabular}

B.APPD CFS.DOC 


\section{REPORT DOCUMENTATION PAGE}

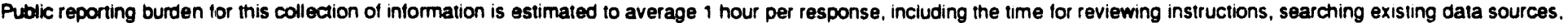

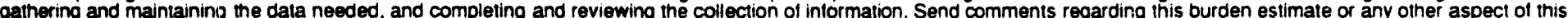

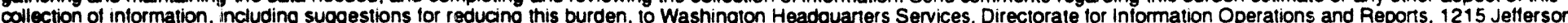
Davis Hignway. Suite 1204. Antington, VA 22202-4302. and to the Office of Management and Budget, Paperwork Reduction Project (0704-0188). Washington, DC 20503.

\begin{tabular}{|l|l|l}
\hline 1. AGENCY USE ONLY (Leave blank) & $\begin{array}{c}\text { 2. REPORT DATE } \\
\text { August 1994 }\end{array}$ & $\begin{array}{l}\text { 3. REPORT TYPE AND DATES COVERED } \\
\text { Subcontract Repont }\end{array}$ \\
\hline
\end{tabular}

\section{TITLE AND SUBTITLE}

\section{FUNDING NUMBERS}

Diesel Fuel Cumponent Contributions to Engine Emissions and Performance: Clean Fuel Study

(C) YZ-2-11215-1

(TA) FU421010

\section{AUTHOR(S)}

J. Enwin. T.W. Ryan III, D.S. Moulten, DOE Alemative Fuel Center

\section{PERFORMING ORGANIIZATION NAME(S) AND ADDRESS(ES)}

Southwest Research Institute

6220 Culebra Road

P.O. Drawer 28510

San Amtonio, TX 78228-0510

\section{SPONSORINGMONITORING AGENCY NAME(S) AND ADDRESS(ES)}

National Renewable Energy Laboratory

1617 Cole Boulevard

Golden, CO $80401-3393$

\section{SUPPLEMENTARY NOTES}

\section{2a. DISTRIBUTION/AVAILABILITY STATEMENT}

Netional Technical Information Service

J.S. Department of Commerce

5285 Port Royal Road

Springfield, VA 22161
8. PERFORMING ORGANIZATION REPORT NUMBER

SWRI-476415

10. SPONSORINGMONITORING AGENCY REPORT NUMBER

NRELTP-425-6355

\section{ABSTRACT (Maximum 200 words)}

The overall goal of this project was to develop relationships between the composition and properties of various petroleum and atlemative fuel stocks and the emissions and combustion characteristics of these fuets. This was done in a series of experiments in which several fuets were tested in both a constant volume combustion apparatus and a single-cytinder research engine. The results of the fuel processing and characterization studies, and the preliminary engine test fuels were reported in three peer-reviewed technical papers. The immediate goals of the Clean Fuel Study are discussion of the results of statistical analysis of these data, and the utilization of the results of these analyses to develop several formulations of low emissions diesel fuels.

\section{SUBJECT TERMS}

diesel fuel, emissions, engine design, clean fuets
15. NUMBER OF PAGES

39

16. PRICE CODE

\section{SECURITY CLASSIFICATION} OF REPORT
18. SECURITY CLASSIFICATION OF THIS PAGE
19. SECURITY CLASSIFICATION OF ABSTRACT
20. LIMITATION OF ABSTRACT

Standard Form 298 (Rev. 2-89) Prescribed by ANSI Sid Z39-1E 298-10: 

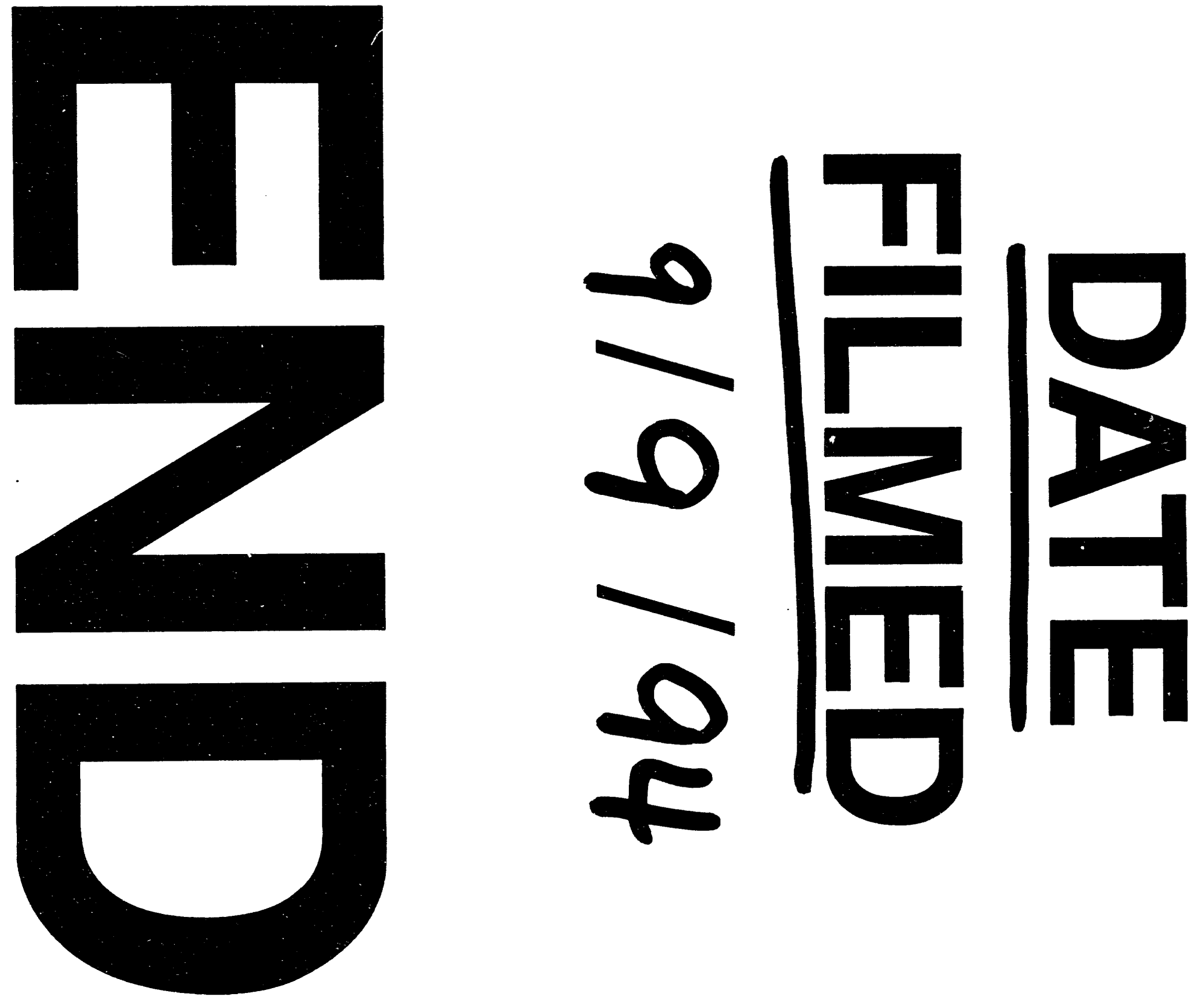
